\title{
The observed influence of local anthropogenic pollution on northern Alaskan cloud properties
}

\author{
Maximilian Maahn ${ }^{1,2}$, Gijs de Boer ${ }^{1,2}$, Jessie M. Creamean ${ }^{1,2}$, Graham Feingold ${ }^{2}$, Greg M. McFarquhar ${ }^{3}$, Wei Wu ${ }^{4,5}$, \\ and Fan $\mathrm{Mei}^{6}$ \\ ${ }^{1}$ University of Colorado, Cooperative Institute for Research in Environmental Sciences, Boulder, Colorado, USA \\ ${ }^{2}$ National Oceanographic and Atmospheric Administration, Earth System Research Laboratory, Boulder, Colorado, USA \\ ${ }^{3}$ University of Oklahoma, Cooperative Institute for Mesoscale Meteorological Studies, Norman, Oklahoma, USA \\ ${ }^{4}$ University of Illinois at Urbana-Champaign, Urbana, Illinois, USA \\ ${ }^{5}$ National Center for Atmospheric Research, Boulder, Colorado, USA \\ ${ }^{6}$ Pacific Northwest National Laboratory, Richland, Washington, USA
}

Correspondence to: Maximilian Maahn (maximilian.maahn@colorado.edu)

Received: 31 March 2017 - Discussion started: 16 May 2017

Revised: 19 October 2017 - Accepted: 6 November 2017 - Published: 11 December 2017

\begin{abstract}
Due to their importance for the radiation budget, liquid-containing clouds are a key component of the Arctic climate system. Depending on season, they can cool or warm the near-surface air. The radiative properties of these clouds depend strongly on cloud drop sizes, which are governed in part by the availability of cloud condensation nuclei. Here, we investigate how cloud drop sizes are modified in the presence of local emissions from industrial facilities at the North Slope of Alaska. For this, we use aircraft in situ observations of clouds and aerosols from the 5th Department of Energy Atmospheric Radiation Measurement (DOE ARM) Program's Airborne Carbon Measurements (ACMEV) campaign obtained in summer 2015. Comparison of observations from an area with petroleum extraction facilities (Oliktok Point) with data from a reference area relatively free of anthropogenic sources (Utqiagivik/Barrow) represents an opportunity to quantify the impact of local industrial emissions on cloud properties. In the presence of local industrial emissions, the mean effective radii of cloud droplets are reduced from 12.2 to $9.4 \mu \mathrm{m}$, which leads to suppressed drizzle production and precipitation. At the same time, concentrations of refractory black carbon and condensation nuclei are enhanced below the clouds. These results demonstrate that the effects of anthropogenic pollution on local climate need to be considered when planning Arctic industrial infrastructure in a warming environment.
\end{abstract}

\section{Introduction}

Liquid-containing clouds are a significant modulator of the Arctic climate system's radiation budget. Their properties impact both shortwave and longwave radiative transfer, resulting in seasonally dependent influences that include both net cooling and warming of the Arctic surface (Intrieri et al., 2002; Shupe and Intrieri, 2004), as well as various forms of cloud feedbacks (Colman, 2003). At the same time, liquid cloud droplet number concentration and size are influenced by the number of available cloud condensation nuclei. It has been proposed that this has an effect on cloud albedo, life cycle, and longwave emissivity (Twomey, 1976; Albrecht, 1989; Garrett and Zhao, 2006). Long-range transport of aerosol particles from lower latitudes in winter and early spring (Arctic haze) and episodic forest fires in summer can lead to higher aerosol concentrations (Shaw, 1995; Law and Stohl, 2007), which have been found to modify liquidand mixed-phase cloud properties (Garrett et al., 2004; McFarquhar et al., 2011; Jackson et al., 2012; Zamora et al., 2016). Besides these transported emissions, the Arctic is an environment that is generally relatively clean with respect to anthropogenic emissions (Quinn et al., 2002, 2009). The generally low cloud condensation nuclei $(\mathrm{CCN})$ concentrations make clouds particularly susceptible to an increase in CCN concentration (Platnick and Twomey, 1994). For example, Croft et al. (2016) showed that emissions from seabird colonies can significantly modify radiative properties of Arc- 
tic summertime cloud. In comparison to other regions, there are only a few sources of local anthropogenic emissions north of the Arctic Circle, which are mainly related to ship traffic and petroleum as well as natural gas extraction facilities (Law and Stohl, 2007). While emissions from ships are expected to rise due to the retreating sea ice, emissions from resource extraction are expected to remain at present-day levels (Peters et al., 2011) with an estimated $13 \%$ of the world's untapped oil resources located in the Arctic (Gautier et al., 2009). Local emissions by Arctic petroleum and natural gas extraction facilities have been observed and quantified by aircraft campaigns (Brock et al., 2011; Roiger et al., 2015). These emissions are mostly associated with flaring, but also by regular internal combustion engines. Ødemark et al. (2012) found that black carbon (BC), which is particularly created by flaring (Stohl et al., 2013), results in a modelled positive net radiative forcing of petroleum and natural gas extraction, mainly due to deposition of $\mathrm{BC}$ on the snow. Kolesar et al. (2017) showed that emissions from the Prudhoe Bay area result in in situ particle growth events in Utqiagivik (formerly known as Barrow), located around $300 \mathrm{~km}$ west of the Prudhoe Bay region. Although these previous studies have demonstrated the potential impact from industrial activities in the Arctic, in situ aerosol and cloud observations have not been combined in order to study local sources of emissions.

In this work, we show how cloud properties are altered by aerosol particles originating from local anthropogenic pollution from industrial activities in the Prudhoe Bay area in northern Alaska (Fig. 1), and we investigate the influence on processes impacting the cloud life cycle. Even though the work is limited to observations from the North Slope of Alaska, the results are broadly applicable to other Arctic regions with significant industrial activities (e.g. Siberia), although exact details of the types of aerosol effects will be influenced by aerosol concentration, size, and composition. Because of their importance in regulating the surface and top-of-atmosphere energy budgets, we focus here on liquid clouds. Increased cloud droplet concentrations in the Prudhoe Bay, Alaska, area were previously reported by Hobbs and Rangno (1998), although that study could not directly connect these increased concentrations to locally produced aerosol particles due to a lack of aerosol measurements. In this study, we fill this gap by using airborne cloud property and aerosol observations obtained during the US Department of Energy Atmospheric Radiation Measurement (DOE ARM) program's 5th ARM Airborne Carbon Measurements (ACME-V) campaign to study the influence of local pollution on Arctic liquid clouds. An enhanced understanding of the influence is crucial to evaluate the role of clouds and aerosols in a changing Arctic which is warming faster than other regions (Jeffries et al., 2013).

In Sect. 2 we provide background information on the ACME-V campaigns along with details on the various data sets used to conduct our analysis. Following this, we analyse

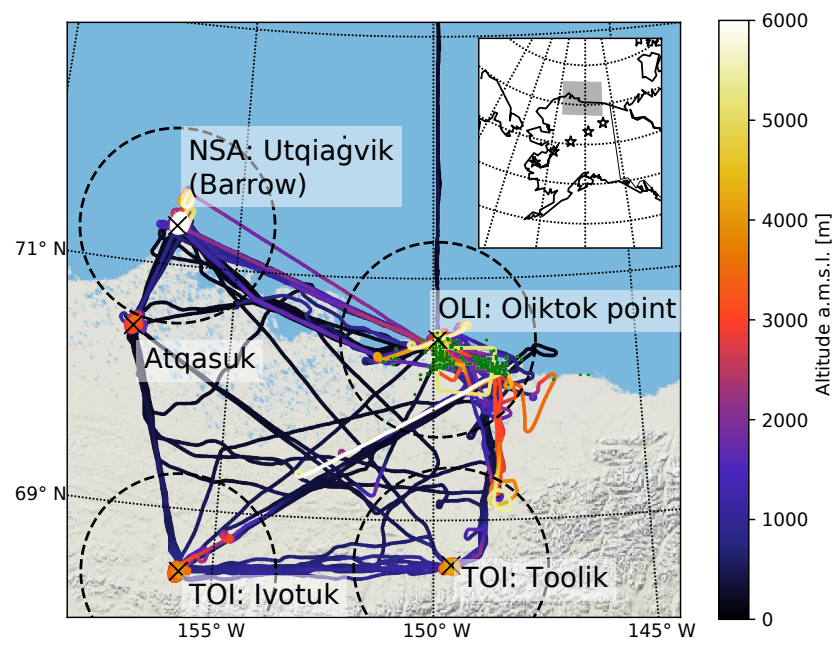

Figure 1. Overview of all flights of the ACME-V campaign. Colour shows altitude above mean sea level. The dashed circles indicate $90 \mathrm{~km}$ radii around the sites (black crosses), the green dots indicate active oil wells (data obtained from http://doa.alaska.gov/ogc/ publicdb.html in March 2017). The grey inset shows the location of the region in Alaska and the five assumed sources for forest fire emissions (stars) based on MODIS thermal anomaly observations.

observed aerosol particle (Sect. 3) and cloud (Sect. 4) properties, before combining these to evaluate the interactions between locally produced aerosols and clouds in Sect. 5. This evaluation is carried further in Sect. 6, where we attempt to quantify observed aerosol-cloud interactions. Finally, we provide a summary and concluding remarks in Sect. 7.

\section{Data set}

The ACME-V aircraft campaign took place from 1 June to 15 September 2015 (Biraud, 2016; ARM, 2016) and consisted of 38 research flights of the ARM Gulfstream G-159 (G-1) aircraft of the ARM aerial facility (Schmid et al., 2014, 2016). Since the campaign targeted trace gas measurements from local and regional sources, a majority of the flight time was spent below $200 \mathrm{~m}$ above mean sea level (a.m.s.l.). However, spirals up to an altitude of $6000 \mathrm{~m}$ were flown in the vicinity of two ARM surface observatories in northern Alaska, Utqiagivik (formerly known as Barrow or ARM's North Slope of Alaska site, NSA; $71.323^{\circ} \mathrm{N}, 156.616^{\circ} \mathrm{W}$ ) and Oliktok Point (OLI; $\left.70.495^{\circ} \mathrm{N}, 149.886^{\circ} \mathrm{W}\right)$. Additional spirals were flown at Toolik $\left(68.628^{\circ} \mathrm{N}, 149.598^{\circ} \mathrm{W}\right)$, Ivotuk $\left(68.483^{\circ} \mathrm{N}, 155.754^{\circ} \mathrm{W}\right)$, and Atqasuk $\left(70.467^{\circ} \mathrm{N}\right.$, $157.436^{\circ} \mathrm{W}$ ) in order to characterise cloud and aerosol properties (Fig. 1). In this work, we compare data within $90 \mathrm{~km}$ of OLI and NSA. These two sites form an ideal opportunity to study the effects of local emissions on cloud properties: while OLI is surrounded by industrial activities related to oil and natural gas extraction (with the majority closer than $90 \mathrm{~km}$ ), no substantial local sources exist in the vicinity of 

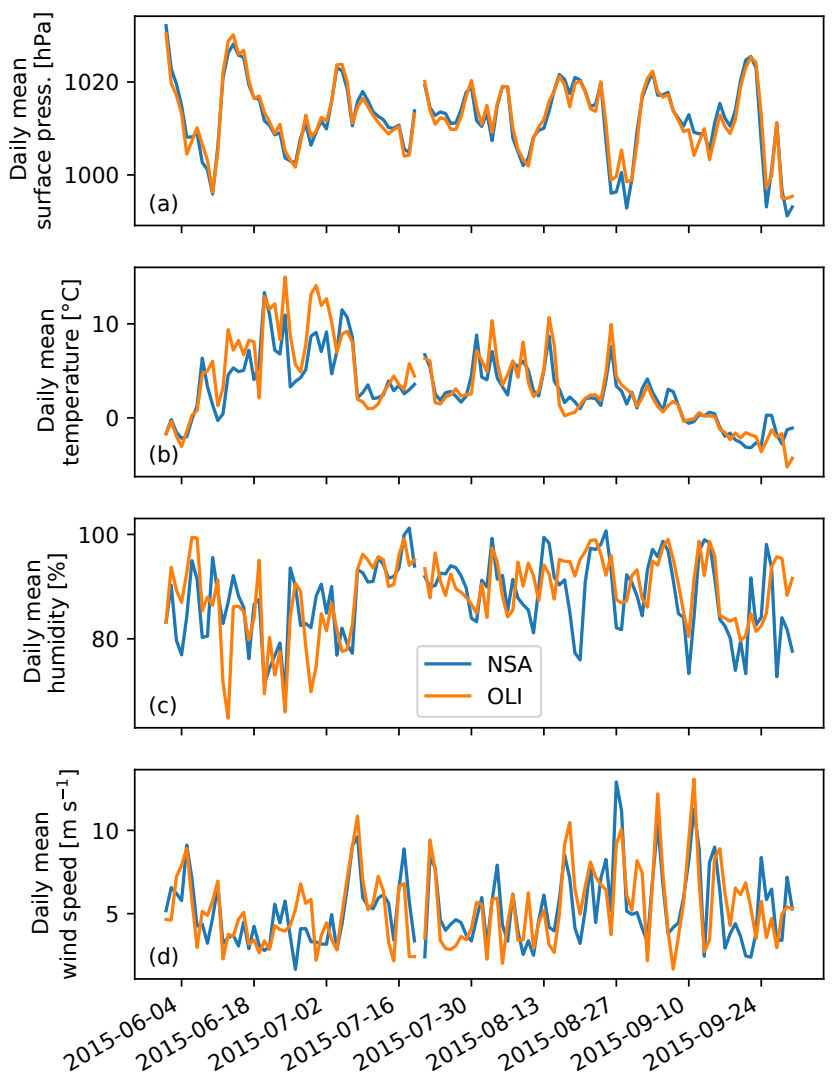

Figure 2. Comparison of daily mean values for (a) surface pressure, (b) $2 \mathrm{~m}$ temperature, (c) $2 \mathrm{~m}$ humidity, and (d) $10 \mathrm{~m}$ wind speed.

NSA and previous studies have shown only limited advection $(8 \pm 2 \%)$ of air masses passing through the Prudhoe Bay area to NSA (Kolesar et al., 2017). Despite substantial differences in aerosol properties, the two coastal sites lie only $250 \mathrm{~km}$ apart, resulting in very similar synoptic-scale forcing, as can be seen from the high correlation between both sites for pressure, temperature, humidity, and wind (Fig. 2). For both sites, north-easterly to easterly winds prevailed during ACME-V (see data set ARM, 1993). Additionally, we grouped observations closer than $90 \mathrm{~km}$ to the two more continental sites Toolik and Ivotuk into a third data set (labelled TOI). During ACME-V, $156(60 \%)$ of the 258 vertically sampled clouds were classified as liquid (see below for thresholds), showing that liquid clouds are frequent during the summer time in northern Alaska. Data obtained during take-off and landing have been removed to avoid skewing the comparison by sampling aerosols and clouds at much lower altitudes than elsewhere.

Cloud properties were observed using a combination of forward scattering and optical array probes. The particle size distributions were measured using a forward-scattering cloud droplet probe (CDP) manufactured by Droplet Measurement Technologies (DMT), Inc., a fast cloud droplet probe (FCDP) from Stratton Park Engineering Company (SPEC), Inc., a two-dimensional stereo optical array probe (OAP) (2DS; Lawson et al., 2006), and a high-volume precipitation spectrometer (HVPS; Lawson et al., 1993) from SPEC, Inc. For the 2DS probe, the evaluation of particle sizing and sample area determination was done following Korolev et al. (1991). The sample areas of CDP and FCDP were determined by their manufacturer using the technique described by Lance et al. (2010). The droplet size response for CDP and FCDP was calibrated weekly using glass beads in field. In addition, liquid water content (LWC) was measured by a multielement water content system (WCM-200) and used for evaluating the in-flight performance of the 2DS, CDP and FCDP (King et al., 1978, 1981, 1985). The raw OAP data sets were processed by the University of Illinois Optical Array Probe Processing Software (Wu and McFarquhar, 2016). In order to merge the cloud droplet size distributions, FCDP data were used for particles less than $50 \mu \mathrm{m}$ size, the 2DS data were used for particles between 50 and $605 \mu \mathrm{m}$, and the HVPS data were used for all particles exceeding $605 \mu \mathrm{m}$. In this study, particle maximum dimension is used in general to describe the size of cloud and aerosol particles. Liquid clouds were required to have at least $10 \mathrm{~cm}^{-3}$ droplets (Lance et al., 2011). We also evaluated the use of a lower cloud threshold $\left(5 \mathrm{~cm}^{-3}\right.$ in accordance with Hobbs and Rangno, 1998), but this only increased the number of observed clouds by two, both of which were classified as impacted by forest fire (see below). In order to avoid sampling errors due to small sample sizes, we use the larger threshold $\left(10 \mathrm{~cm}^{-3}\right)$ in our study. In order to remove ice clouds from the data set, the Holroyd habit classification was applied to 2DS and HVPS observations with $1 \mathrm{~s}$ temporal resolution, which classifies particles mainly based on a fine detail ratio $F=p d / a$, where $p$ is perimeter, $d$ is diameter and $a$ is area (Holroyd, 1987; Wu and McFarquhar, 2016). The habit classification scheme differentiates between spherical particles, tiny particles which are too small to be classified and various forms of ice crystals. Spherical particles were assumed to be liquid. Tiny particles appear only at the lower end of the 2DS $(<105 \mu \mathrm{m})$ and HVPS $(<1125 \mu \mathrm{m})$ size range. They were classified as ice only if other size ranges were not dominated by spherical particles. Otherwise, tiny particles were assumed to be liquid. Data points with more than $100 \mathrm{~m}^{-3}$ particles larger than $400 \mu \mathrm{m}$ (Lance et al., 2011) classified as ice were removed from the data set. This ensures that observations of spherical ice particles falsely classified as liquid, which likely occur together with larger, more complex-shaped ice particles were removed from the data set as well. LWC was obtained by integrating the merged droplet size distribution (DSD), because direct observations of LWC from the King probe (King et al., 1978) are affected by a decreasing sampling efficiency for (drizzle) drops greater than $30 \mu \mathrm{m}$ diameter. Clouds that were observed for less than 10 continuous seconds were discarded, while gaps of up to $5 \mathrm{~s}$ were permitted once in cloud. Considering the typical true airspeed of the G-1 of $95 \mathrm{~m} \mathrm{~s}^{-1}$, 10 and $5 \mathrm{~s}$ correspond to 950 and $475 \mathrm{~m}$, respectively, when 
flying in a straight line. Additionally, only vertically sampled clouds (i.e. the aircraft was constantly ascending or descending) with a sampled vertical extent of at least $20 \mathrm{~m}$ were included in this evaluation to allow for comparison of in-cloud microphysical observations with below-cloud aerosol properties in Sects. 5 and 6. Therefore, very thin and/or small clouds might be discarded inadvertently. To make the detection of cloud boundaries more robust, the cloud probe data were smoothed using a 10 s running average. Except for the detection of the cloud boundaries, effects of the smoothing are negligible for the presented analysis.

Aerosol particles were sampled through an isokinetic inlet with an upper size cut of $5 \mu \mathrm{m}$ (Zaveri et al., 2010; Dolgos and Martins, 2014). Aerosols in the size range $100 \mathrm{~nm}$ to $3 \mu \mathrm{m}$ were observed with a passive cavity aerosol spectrometer (PCASP model 100X, DMT, Inc.) covering most accumulation-mode aerosols (Colbeck and Lazaridis, 2014). We expect particles measured by the PCASP to be mostly dry, because it was operated with an anti-ice heater. Kassianov et al. (2015) showed for the very same aircraft that this assumption leads to good agreement between calculated (also using PCASP observations) and measured scattering properties. The PCASP was calibrated using both size-selected ammonium sulfate particles and monodisperse polystyrene latex (PSL) spheres. The sizing accuracy was checked weekly in the field using PSL particles following Cai et al. (2013). Unfortunately, another aerosol sampler (ultra-high-sensitivity aerosol sizer, UHSAS), which is able to detect aerosols below the PCASP detection threshold of $100 \mathrm{~nm}$, did not operate during the majority of the ACME$\mathrm{V}$ flights. Two condensation particle counters (CPCs, TSI, Inc., models 3025 and 3010) were used to observe total number concentrations of condensation nuclei $(\mathrm{CN})$ for the size ranges $3 \mathrm{~nm}-3 \mu \mathrm{m}$ and $10 \mathrm{~nm}-3 \mu \mathrm{m}$, respectively. CPC calibration activities included verifying inlet flow rate with a low pressure-drop bubble flow meter, and determining the sizedependent particle counting efficiency, according to methods defined in Hermann et al. (2007) and Mordas et al. (2008). Unless otherwise stated, only the CPC 3025 featuring a size range of $3 \mathrm{~nm}-3 \mu \mathrm{m}$ is used in this evaluation. The mass and core size of black carbon (BC), which results from incomplete combustion of biomass and fossil fuels (Schwarz et al., 2008; Bond et al., 2013; Lack et al., 2014), was measured with a single-particle soot photometer (SP2, from DMT, Inc.), via incandescence. Thus, only refractory black carbon $(\mathrm{rBC})$ is observed by the instrument. The applied SP2 calibration methods using ambient $\mathrm{BC}$ and fullerene soot are described in detail by Gysel et al. (2011) and Irwin et al. (2013). The fullerene soot and PSL calibration were performed twice during this field campaign and the sensitivity of the SP2 was found to be stable to around $10 \%$ for fullerene soot particles, resulting in an estimated SP2 measurement uncertainty of $10 \%$. Concentrations of carbon monoxide $(\mathrm{CO})$ were detected with a Los Gatos Research $\mathrm{CO} / \mathrm{N}_{2} \mathrm{O} / \mathrm{H}_{2} \mathrm{O}$ analyser. A counter for cloud condensation nuclei $(\mathrm{CCN})$ was not deployed during ACME-V. The temporal resolution of the aerosol probes is $1 \mathrm{~s}$ with the exception of the SP2 $(10 \mathrm{~s})$.

Transported emissions from forest fires can contribute significantly to summertime aerosol loading in the Arctic (Law and Stohl, 2007; Creamean et al., 2017). Therefore, we manually inspected the vertical profiles of $\mathrm{rBC}$ and $\mathrm{CO}$, which together can be used to trace biomass burning in otherwise clean environments (Warneke et al., 2009, 2010; Zamora et al., 2016). Typically, these layers are found aloft (Roiger et al., 2015), allowing us to use vertical profiles obtained by the aircraft to aid in their identification. For each spiral obtained at the two sites, elevated layers with $\mathrm{CO} \geq 0.1 \mathrm{ppmv}$ or $\mathrm{rBC} \geq 20 \mathrm{ng} \mathrm{kg}^{-1}$ were flagged as potentially associated with forest fires. Local emissions, on the other hand, are expected to be concentrated in the boundary layer. Note that the data impacted by forest fires were only removed for spirals above OLI, NSA, and TOI. For clear-air observations during level flight legs between sites, it is generally impossible to determine whether a layer is connected to the surface or elevated. For ACME-V, Creamean et al. (2017) classified only four flights as impacted by long-range transport from lower latitudes not related to forest fires. During these flights, only a single cloud was sampled in the vicinity of OLI or NSA which had one of the lowest aerosol concentrations measured in the whole data set. Therefore we are confident that our analysis is not strongly impacted by these kinds of long-range transport events.

The manual inspection was supported by aerosol dispersion simulations executed using version 4 of the Hybrid Single Particle Lagrangian Integrated Trajectory (HYSPLIT) model (Stein et al., 2015). These simulations were forced using $1^{\circ}$ data from the NOAA/NCEP Global Data Assimilation System (GDAS) (Kalnay et al., 1996). Five locations were included as sources (see Fig. 1: (1) $62.096^{\circ} \mathrm{N}, 163.632^{\circ} \mathrm{W}$; (2) $63.843^{\circ} \mathrm{N}, 159.046^{\circ} \mathrm{W}$; (3) $65.294^{\circ} \mathrm{N}, 154.386^{\circ} \mathrm{W}$; (4) $66.631^{\circ} \mathrm{N}, 149.023^{\circ} \mathrm{W}$; and (5) $67.631^{\circ} \mathrm{N}, 144.087^{\circ} \mathrm{W}$ ). These sources were toggled on or off on a daily basis in correspondence to thermal anomaly observations in the corresponding region (see Fig. 4 of Creamean et al., 2017) from the Moderate Resolution Imaging Spectroradiometer (MODIS) on the Aqua and Terra satellites obtained using brightness temperature measurements in the 4 and $11 \mu \mathrm{m}$ channels (Giglio et al., 2003; Giglio, 2013). From each fire location, particle mass concentrations were simulated for $72 \mathrm{~h}$ at $100 \mathrm{~m}$ intervals from 0 to $5000 \mathrm{ma}$ a.g.l. Both dry and wet deposition were considered for particles using the default HYSPLIT parametrisations (particle density $6 \mathrm{~g} \mathrm{~cm}^{-3}$, shape factor 1.0). The particle diameter of $0.2 \mu \mathrm{m}$ used for the simulations is based on previous observations from fossil fuel and biomass burning sources (Brock et al., 2011; Eck et al., 1999; Rissler et al., 2006; Sakamoto et al., 2015). A dry deposition velocity of $1 \times 10^{-4} \mathrm{~m} \mathrm{~s}^{-1}$ was assumed according to Warneck (1999), while $4 \times 10^{4} \mathrm{LL}^{-1}$ and $5 \times 10^{-6} \mathrm{~s}^{-1}$ were used to account for in-cloud and below-cloud wet deposition scavenging, respectively. Radioactive decay and pollu- 
tant resuspension were not considered. For the spirals, data identified as originating from forest fire either from manual inspection or according to HYSPLIT, were removed from subsequent analysis. With this approach, we likely removed more clouds from the analysis than required. This, however, ensures that the analysis of the remaining clouds is not biased by influences from forest fires.

\section{Aerosol properties}

The spatial distribution of aerosol observations below $500 \mathrm{~m}$ a.m.s.l. are presented for the CPC, the SP2, and the PCASP in Fig. 3. As discussed above, removal of data potentially impacted by forest fires is only possible for the spirals. Therefore, the data presented in Fig. 3 are limited to observations obtained below $500 \mathrm{~m}$, because transported emissions of forest fires were typically at higher altitudes during ACME-V (for a detailed study of aerosol properties during ACME-V see Creamean et al., 2017). Furthermore, aerosol data flagged as sampled in cloud using the thresholds described in the previous section were discarded in the analysis of aerosol properties due to concerns of contamination of the statistics by shattering of cloud droplets.

A clear local maximum of $\mathrm{rBC}$ mass concentration is visible east of OLI in the SP2 data within the $90 \mathrm{~km}$ radius (Fig. 3a) where most petroleum and gas extraction facilities are located (Fig. 1). A comparison of the distributions measured within a $90 \mathrm{~km}$ radius around the facilities at NSA and OLI reveals that the median $\mathrm{rBC}$ concentration is the same for both regions $\left(4 \mathrm{n} \mathrm{kg}^{-1}\right)$. The tail and the number of outliers of the distributions towards larger concentrations, however, are greater at OLI (90th and 99.9th percentile 17 and $198 \mathrm{ng} \mathrm{kg}^{-1}$, respectively) than at NSA (15 and $42 \mathrm{ng} \mathrm{kg}^{-1}$, respectively). $\mathrm{rBC}$ is a tracer for combustion emissions (Bond et al., 2004). Because the height threshold of $500 \mathrm{~m}$ reduces the impact of forest fires, this enhancement is most likely connected to local emissions. CN measurements from the CPC show a spatial pattern similar to the SP2 even though the increased values are distributed over a larger area (Fig. 3b). For both instruments, the distributions within the $90 \mathrm{~km}$ circle belonging to each site are skewed towards higher concentrations and the distributions of both sites are significantly different (1\% confidence interval) according to the two-sample Kolmogorov-Smirnov (KS) test (Massey Jr., 1951). Further, the difference between the two $\mathrm{CPC}$ instruments, which equates to the concentration of $\mathrm{CN}$ between 3 and $10 \mathrm{~nm}$ diameter, is enhanced in the OLI region and the distribution is significantly (KS test) different to the one at NSA (Fig. 3c). Because this quantity is stemming from the difference in two instruments at the limit of their measurement range, the data are used here only in a qualitative way. Freshly emitted soot has been shown to be larger than $15 \mathrm{~nm}$ (Zhang et al., 2008), so particles in the $3-10 \mathrm{~nm}$ size range are likely due to in situ nucleation
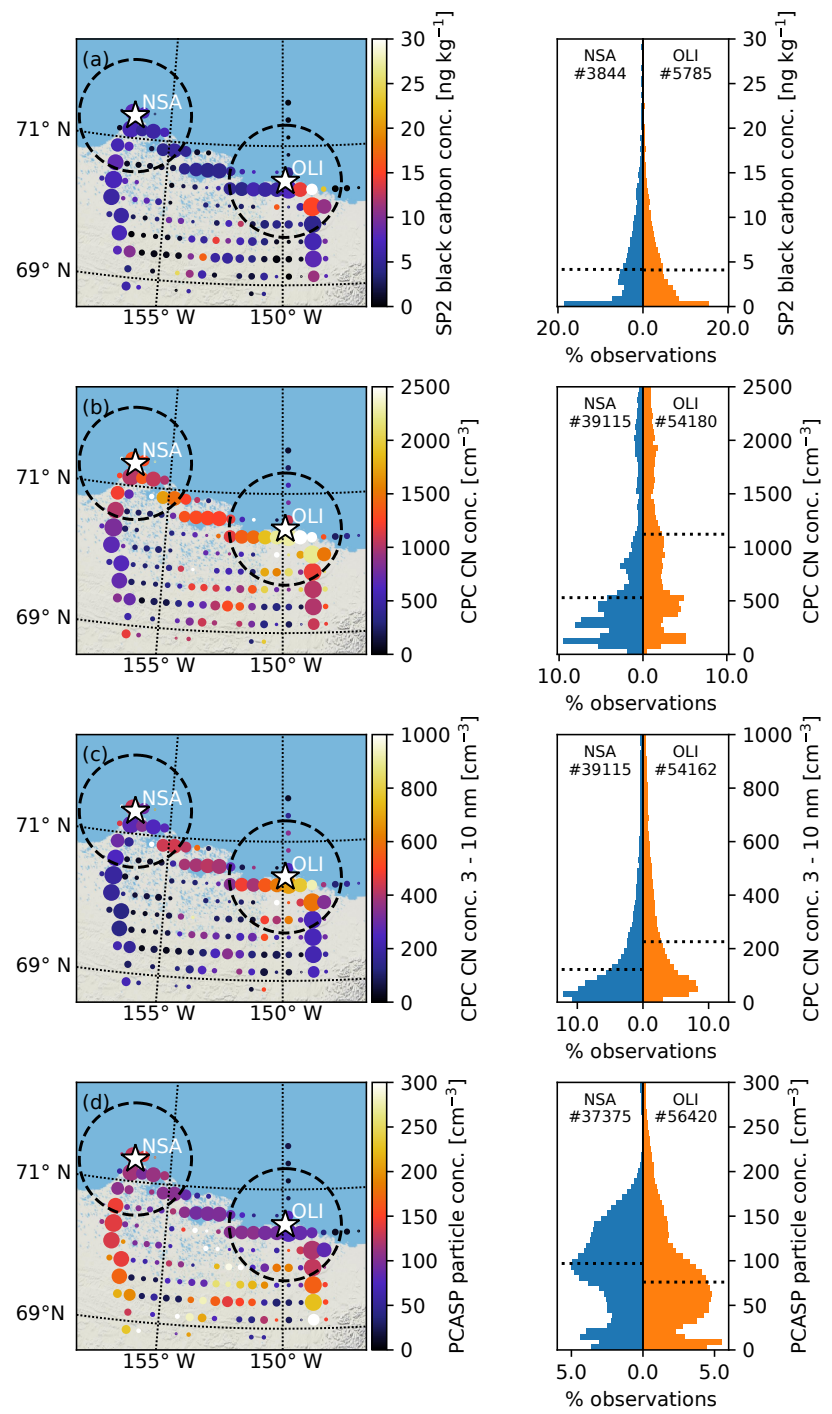

Figure 3. Left column: spatial distribution of mean (a) SP2 refractory black carbon concentration, (b) CPC3025 CN concentrations, (c) difference between CPC3025 and CPC3010 CN concentration corresponding to a size range of 3 to $10 \mathrm{~nm}$, and (d) PCASP aerosol concentration. Only non-cloudy observations below $500 \mathrm{~m}$ a.m.s.1. have been considered. The size of the dots is proportional to the number of observations. The dashed circles correspond to a distance of $90 \mathrm{~km}$. Right column: here, the distribution of measurements within the $90 \mathrm{~km}$ circles are shown; the number above the distribution shows the number of observations. The horizontal dotted bar denotes the median value.

of aerosol particles from gas-phase precursors (i.e. formation of new particles as compared to secondary aerosol formation, where gases condense onto preexisting aerosol; Kulmala et al., 2012). Nucleated aerosols typically have sizes below $3 \mathrm{~nm}$ but quickly grow via condensation and coagulation to sizes $>3 \mathrm{~nm}$ (Colbeck and Lazaridis, 2014). This source of nucleated aerosol particles from petroleum and gas extraction activities (e.g. flaring and venting of gas) has been 

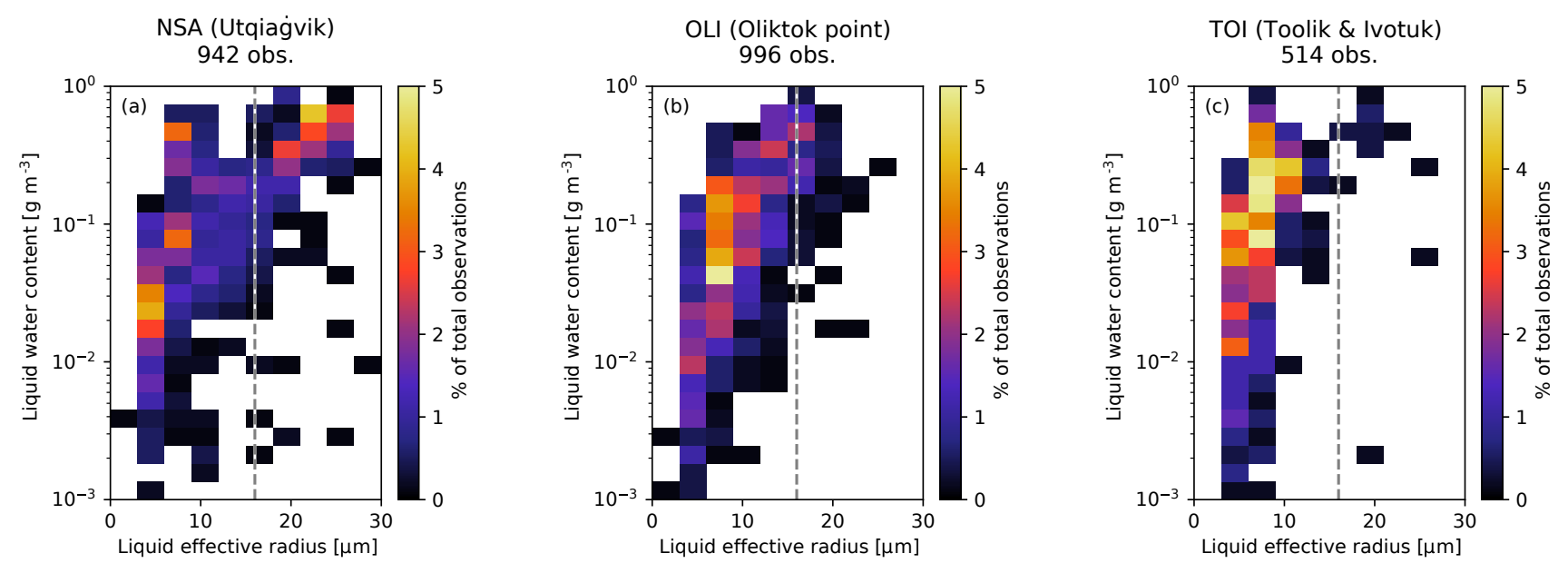

Figure 4. Two-dimensional histogram of number of observations as a function of effective radius $r_{\text {eff }}$ and liquid water content LWC for NSA (Utqiagivik/Barrow) (a), OLI (Oliktok Point) (b), and TOI (Toolik/Ivotuk) (c). The dashed line indicates a $r_{\mathrm{eff}}$ value of $16 \mu \mathrm{m}$.

reported by Kolesar et al. (2017) for emissions transported from OLI to NSA.

Unfortunately, we cannot analyse this aerosol nucleation process in more depth given limitations with the instrumentation operated during ACME-V. rBC background concentrations appear to be similar to background observations made by Zamora et al. (2016) and Roiger et al. (2015). It should be noted that emissions related to forest fires led to concentrations as high as $600-1000 \mathrm{ng} \mathrm{kg}^{-1}$ during ACME-V (mostly at altitudes above $500 \mathrm{~m}$; Creamean et al., 2017), which were also observed in other data sets (Warneke et al., 2009; Schwarz et al., 2010; Zamora et al., 2016). Consequently, the emissions from anthropogenic sources in the OLI region are about a magnitude lower. In contrast to $\mathrm{CO}$ concentrations sampled in air masses originating from forest fires, low-altitude $\mathrm{CO}$ concentrations in the OLI region were not enhanced relative to background values (Creamean et al., 2017). The differences between $\mathrm{CO}$ and $\mathrm{rBC}$ concentrations attributed to forest fires and the concentrations measured in the OLI region show that our approach to use $\mathrm{CO}$ and $\mathrm{rBC}$ to separate observations impacted by forest fires is feasible.

The PCASP, which detects only particles larger than $100 \mathrm{~nm}$, shows no spatial trends in the vicinity of the two sites (Fig. 3d). The comparison of the distributions around the facilities shows that the number of aerosols observed by the PCASP is on average actually slightly larger for NSA than for OLI. This is related to the fact that the median of the distribution is $97 \mathrm{~cm}^{-3}$ at NSA and $76 \mathrm{~cm}^{-3}$ at OLI. Similar to $\mathrm{rBC}$, the tail of the distributions towards larger concentrations is greater at OLI (90th percentile $200 \mathrm{~cm}^{-3}$ ) than at NSA $\left(184 \mathrm{~cm}^{-3}\right)$ and the difference in the distributions is significant according to the KS test with $1 \%$ confidence interval. While it is challenging to clarify the precise cause of the increased mean concentration in detail, we speculate it might be related to transported emissions, including those from forest fires, that have not been properly removed from the data set because they are highly diluted. Transported forest fire aerosols are often larger than the PCASP detection threshold of $100 \mathrm{~nm}$ as shown by Kondo et al. (2011) and Sakamoto et al. (2015). An alternative explanation could be the fact that collision-coalescence and precipitation rates are larger at NSA than at OLI (see next section), resulting in more aerosol processing by precipitation (e.g. Feingold et al., 1996). Cloud-based processing leads to a reduction in aerosol concentration and an increase in aerosol size through conglomeration of cloud droplets (and corresponding aerosol particles) in the drizzle formation stage and subsequent evaporation. Such effects could increase the number of aerosols within the PCASP measurement size range.

\section{Cloud properties}

Here, cloud properties are compared for flights occurring near NSA and near OLI. In order to evaluate a sufficiently large sample, all observations obtained closer than $90 \mathrm{~km}$ to NSA, OLI and the two sites comprising TOI are assigned to the corresponding site (Fig, 1). Data obtained at altitudes above $500 \mathrm{~m}$ are also considered, but clouds impacted by forest fires have been removed based on the vertical profile as mentioned above. This limits the number of observations to 996 one-second data points for OLI, 942 for NSA, and 514 for TOI. The data set contains mostly shallow (median cloud depth $107 \mathrm{~m}$ ) stratus and stratocumulus clouds with a cloud base between 178 and $5346 \mathrm{~m}$ (median of $1498 \mathrm{~m}$ ).

When comparing 2-D histograms of liquid effective radius and liquid water content for OLI and NSA (Fig. 4a and b), OLI values are shown to feature smaller $r_{\text {eff }}$ for the same LWC. The effect is most pronounced for LWC > $0.1 \mathrm{~g} \mathrm{~m}^{-3}$ (Leaitch et al., 1992), while distributions for LWC $<0.1 \mathrm{~g} \mathrm{~m}^{-3}$ are more similar. Note that LWC values 

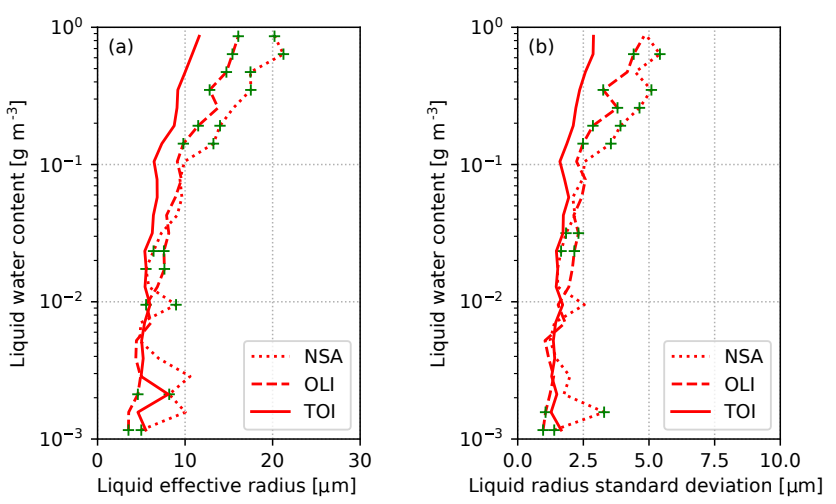

Figure 5. (a) Mean $r_{\text {eff }}$ and (b) mean SD as a function of LWC for the data presented in Fig. 4. The green crosses indicate a significant difference between OLI and NSA (5\% confidence interval).

below $0.01 \mathrm{~g} \mathrm{~m}^{-3}$ are defined as not in cloud by some studies (e.g. Matsui et al., 2011; Leaitch et al., 2016), but we decided to show the full data set because the in-cloud definition used here $\left(>10\right.$ droplets $\mathrm{cm}^{-3}$ ) can result in LWC as low as $0.001 \mathrm{~g} \mathrm{~m}^{-3}$ and we wanted to make sure that all cloud data points are included in the analysis. The decrease in $r_{\text {eff }}$ supports our hypothesis that $\mathrm{CCN}$ concentrations are elevated in the OLI region, since the first aerosol-cloud indirect effect proposes that droplet size is reduced when more CCN are available (all else equal). While droplet $r_{\text {eff }}$ observed at NSA cover the full range from droplet nucleation to drizzle $(3-25 \mu \mathrm{m}$, mean $12.2 \pm 6.9 \mu \mathrm{m}), r_{\text {eff }}$ values are typically smaller than $16 \mu \mathrm{m}$ at OLI (mean $9.4 \pm 4.1 \mu \mathrm{m}$ ) and observations of drizzle-sized droplets are rare. The value of $16 \mu \mathrm{m}$ is of special interest because it was proposed by Gerber (1996) as a minimal effective radius required to initiate collisioncoalescence. Figure 5a reveals that this difference is statistically significant for most $\mathrm{LWC}>0.1 \mathrm{~g} \mathrm{~m}^{-3}$ according to a Welch's $t$ test (Welch, 1947) with a $5 \%$ confidence interval (note that a $5 \%$ confidence interval is always used in this study unless noted otherwise). For comparison, data obtained in a $90 \mathrm{~km}$ radius around Toolik and Ivotuk (TOI) (Fig. 4c) reveal that the distribution of observed $r_{\mathrm{eff}}$ at the coastal site in OLI is still larger to the inland sites comprising TOI (mean $7.2 \pm 3.1 \mu \mathrm{m}$ ) than to the second coastal site, NSA. For TOI, the mean $r_{\text {eff }}$ is significantly different than those at NSA for $\mathrm{LWC}>0.02 \mathrm{~g} \mathrm{~m}^{-3}$. Figure $5 \mathrm{~b}$ reveals that not only the mean $r_{\text {eff }}$ at OLI but also the breadth of the distribution is reduced, as shown by the SD. This difference is significant for most data points with $\mathrm{LWC}>0.1 \mathrm{~g} \mathrm{~m}^{-3}$.

The Albrecht effect proposes that more polluted clouds have longer cloud lifetime due to less efficient collisioncoalescence (Albrecht, 1989). It is not possible to study the cloud life cycle using aircraft in situ observations, but the potential for impact on cloud life cycle can be estimated by calculating the collection growth rate $C$ (Long, 1974) and precipitation rate $R$. Even though the rate of mass removal from a cloud is an important process impacting cloud life cycle, it is important to note that modifications to $C$ and $R$ cannot be directly translated into modifications in cloud lifetime. This is because a reduction in $R$ could result in a number of feedbacks such as cloud deepening (Stevens and Feingold, 2009) or reduced evaporation just below cloud base (Feingold and Siebert, 2009) that would act to counter the extending effect of reduced precipitation rate on cloud lifetime.

$C$ describes the mass of drops collected by a unit mass in a unit volume $M$ per time interval $t$. It is the key process for converting cloud drops into precipitation and is estimated by integrating the mass collected by particles with diameter $D_{1}$ and mass $m_{1}$ over all size bins:

$C=\frac{\mathrm{d} M}{\mathrm{~d} t}=\int_{D_{\min }}^{D_{\max }} \frac{\mathrm{d} m_{1}}{\mathrm{~d} t} N\left(D_{1}\right) \mathrm{d} D_{1}$,

where $N\left(D_{1}\right)$ is the particle number distribution function and $D_{\min }$ and $D_{\max }$ are the bounding drop diameters as determined by the cloud probes $(0.75 \mu \mathrm{m}$ and $8.7 \mathrm{~mm}) . \mathrm{d} m_{1} / \mathrm{d} t$ is obtained by integrating the collection kernel $K$ for all smaller size bins (i.e. $D_{1}>D_{2}$ ) described by the diameter of the collected drops $D_{2}$

$$
\frac{\mathrm{d} m_{1}}{\mathrm{~d} t}=\frac{\pi \rho_{\mathrm{w}}}{6} \lim _{D_{1} \rightarrow D^{\prime}} \int_{D_{\min }}^{D^{\prime}} K\left(D_{1}, D_{2}\right) N\left(D_{2}\right) D_{2}^{3} \mathrm{~d} D_{2},
$$

where $\rho_{\mathrm{w}}$ is the density of liquid water. For simplicity, here we use a simple polynomial approximation of $K$

$$
K\left(D_{1}, D_{2}\right) \approx \begin{cases}5.78 \times 10^{3}\left(v_{1}+v_{2}\right) & 20 \mu \mathrm{m} \leq D_{1} \leq 100 \mu \mathrm{m} \\ 9.44 \times 10^{9}\left(v_{1}^{2}+v_{2}^{2}\right) & D_{1}>100 \mu \mathrm{m},\end{cases}
$$

where $v_{i}$ is the drop volume corresponding to $D_{i}$ (Long, 1974; Pruppacher and Klett, 2010). Typical values for $C$ range from $1 \times 10^{-16} \mathrm{~kg} \mathrm{~m}^{-3} \mathrm{~s}$ for $\mathrm{LWC}=0.001 \mathrm{~g} \mathrm{~m}^{-3}$ to $1 \times 10^{-5} \mathrm{~kg} \mathrm{~m}^{-3} \mathrm{~s}$ for LWC $=1 \mathrm{~g} \mathrm{~m}^{-3}$. Note that our approximation does not consider the impact of turbulence and droplet charge on $C$. This might lead to considerable uncertainties, which have - to the authors' best knowledge - not been fully quantified. Because we are interested in how $C$ is modified in the OLI region, we focus on the ratio of $C$ determined at NSA and OLI, which should reduce the uncertainty of $C$. Figure 6 shows the ratio between NSA and OLI of $C$ as a function of $r_{\text {eff }}$ and LWC. It can be seen that $C$ is decreased at OLI in comparison to NSA by up to 1 order of magnitude for constant LWC and $r_{\text {eff. }}$. This is caused by reduced broadening of the drop size distribution towards large drops at OLI (Fig. 5b), consistent with the experiments of Gunn and Phillips (1957), who produced similar results when ingesting polluted background air into their cloud chamber. The difference between both sites is significant for most values with sufficient number of observations 

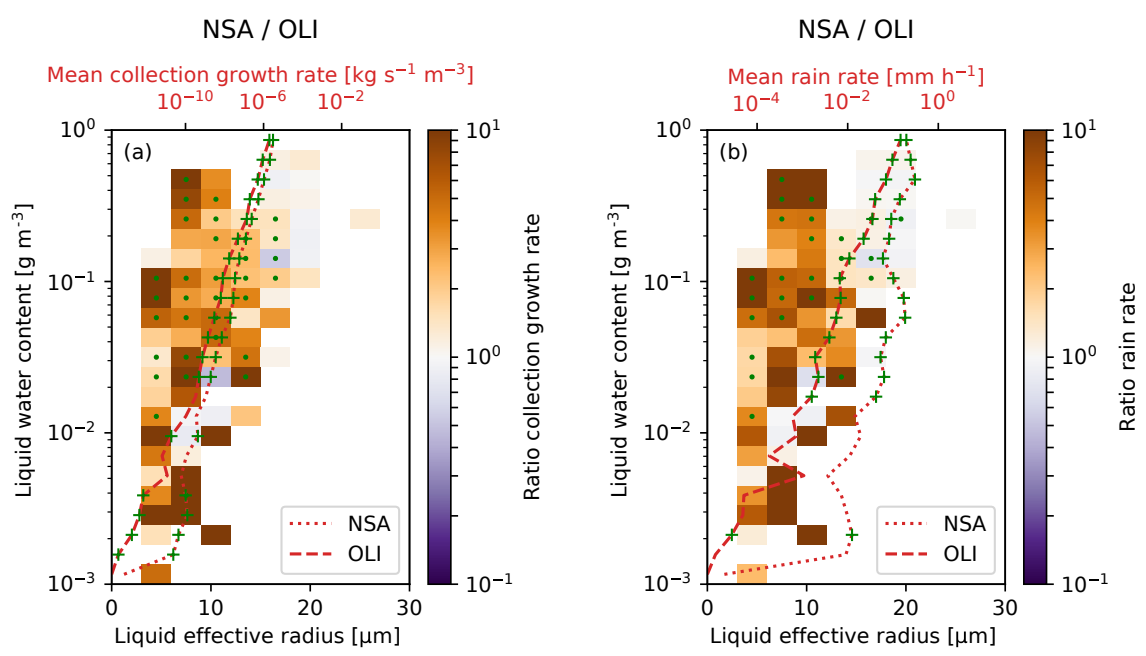

Figure 6. As Fig. 4, but with the coloured shading representing the site-to-site ratio (NSA / OLI) of the collection kernel growth rate $C$ (a) and the rain rate $R$ (b). The rates averaged over $r_{\text {eff }}$ are shown in red for NSA (dotted) and OLI (dashed). The green dots and crosses highlight data points with a significant difference (5\% confidence interval).

for both sites (see Fig. 4). However, small absolute increases in $C$ for small $r_{\text {eff }}$ are also crucial for triggering the positive feedback of drop growth due to collision-coalescence. When evaluating the potential impact of reduced $C$ on cloud life cycle, one also has to consider that typical $r_{\text {eff }}$ values are reduced at OLI in comparison to NSA for the same LWC (Fig. 4a and b). Therefore, we estimate the mean growth rate $\bar{C}$ averaged over $r_{\text {eff }}$ as a function of LWC (Fig. 6a) red lines). Doing so reveals that, for constant $\mathrm{LWC}, \bar{C}$ is reduced by $1-$ 1.5 orders of magnitude at OLI. The offset is significant and surprisingly constant for LWC larger than $0.01 \mathrm{~g} \mathrm{~m}^{-3}$. Differences in $C$ also translate to different rain rates $R$, which can be estimated by integrating the measured DSD and applying the fall velocity parametrisation of Khvorostyanov and Curry (2002) which provides a continuous solution over the entire drop size range in dependence of the Best and Reynolds number. Like $C, R$ is reduced by up to 1 order of magnitude for constant LWC and $r_{\text {eff }}$ (Fig. 6b). Averaging over all $r_{\text {eff }}$ enhances the effect and leads to differences of up to 2 orders of magnitude for $R$ as a function of LWC. This effect is statistically significant for $\mathrm{LWC}>0.02 \mathrm{~g} \mathrm{~m}^{-3}$.

Parametrisations of $C$ and $R$ are crucial in numerical models to transform cloud liquid water into rain droplets and to remove condensate from the atmosphere. Typically, numerical weather and climate models include either one (LWC, one-moment schemes) or two (LWC and drop concentration or $r_{\text {eff }}$, two-moment schemes) prognostic variables per hydrometeor species. Our comparison of $C$ and $R$ for both sites reveals, however, that these quantities vary by up to 1 order of magnitude for constant LWC and $r_{\mathrm{eff}}$ (which would be equivalent to a two-moment scheme). Considering only LWC (i.e. one-moment scheme) increases the differences to 1.5-2 orders of magnitude. As a consequence, additional moments or the full particle size distribution need to be considered in order to accurately estimate $C$ and $R$ in these models. Otherwise, a parametrisation of $C$ or $R$ relying only on LWC (LWC and $r_{\text {eff }}$ ) might be biased by up to 1.5-2 (1) orders of magnitude for one-moment (two-moment) schemes.

\section{Aerosol cloud interaction}

So far, we have demonstrated that there are differences in aerosol properties and cloud properties between NSA and OLI. This is in general agreement with the findings of Hobbs and Rangno (1998), who found an increase in droplet number concentration when flying over Prudhoe Bay. In this section, we present evidence that these changes are indeed connected to local industrial activities centred around the Prudhoe Bay oil fields.

In order to evaluate the likelihood that Prudhoe Bay emissions impacted different portions of the ACME-V flights, we use the HYSPLIT dispersion model. Simulations were completed using one continuously emitting source located over the Prudhoe Bay oilfields $\left(70.2556^{\circ} \mathrm{N}, 148.3384^{\circ} \mathrm{W}\right)$, using a configuration similar to that discussed above for evaluation of wildfire emissions. Note that given the coarse resolution of the forcing model $\left(1^{\circ}\right)$ and the complexity of the Arctic boundary layer, HYSPLIT is used here only in a qualitative way and not to select locally impacted clouds. For OLI (NSA), $50 \%(16 \%)$ of all data points observed within clouds during ACME-V can be traced back to surface emissions (i.e. mass concentration $>0$ according to HYSPLIT) originating from the Prudhoe Bay oilfields. The $16 \%$ determined for NSA is roughly twice that presented in Kolesar et al. (2017). However, they studied aerosol concentration at the surface instead of aloft and used a multi-year data set, which could introduce substantial variability from the 3-month pe- 

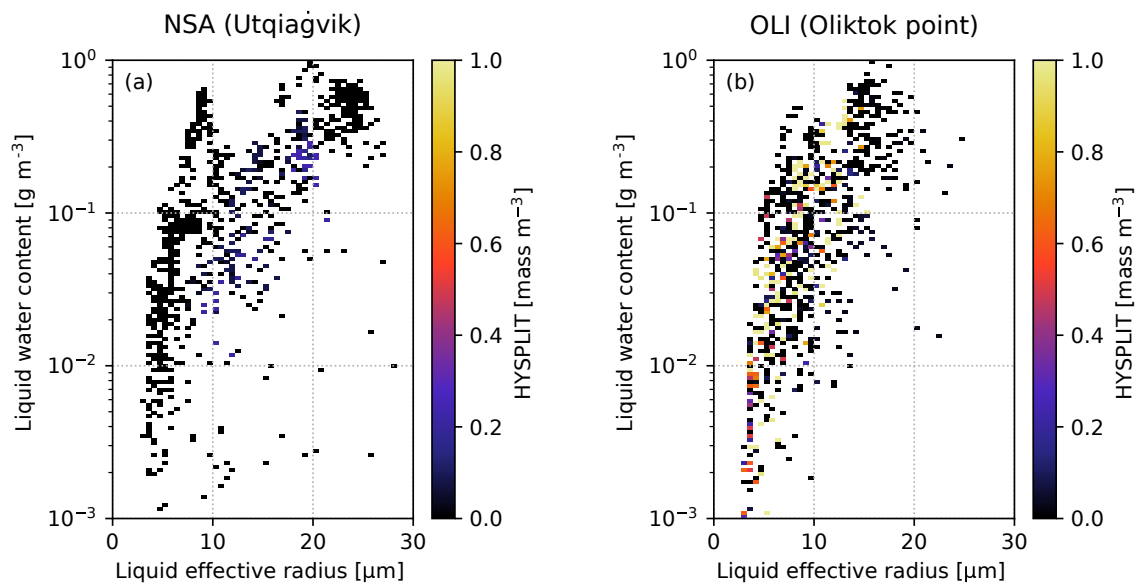

Figure 7. As Fig. 4, but with smaller bin size and mass concentration of local emission according to the HYSPLIT model for NSA (a) and OLI (b).

riod evaluated here. The HYSPLIT simulations (Fig. 7) show that the mass concentration originating from local pollution sources can be a substantially higher at OLI than at NSA, which is consistent with the observed difference of the tail of the PCASP distribution (Fig. 3d). These simulations indicate that relative to NSA, the number of clouds impacted by local emission is higher at OLI and these clouds are impacted by a larger amount of aerosol particles by mass. However, an impact of local emissions on cloud properties is also possible at NSA, although less frequently than at OLI. The bin sizes in Fig. 7 were reduced in order to investigate the variability between clouds. This reveals that only a subset of clouds is associated with local pollution according to HYSPLIT. Note that HYSPLIT provides only a relative emission rate in "mass $\mathrm{m}^{-3}$ " because the actual emission rate in the Prudhoe Bay region is unknown.

Figure 8 relates in-cloud observations of LWC and $r_{\text {eff }}$ to below-cloud observations of $\mathrm{rBC}$ similar to the approach of Jackson et al. (2012). As a consequence, a single belowcloud aerosol value is assigned to every data point within the same cloud based on the assumption that aerosol properties are not changing on the scale of individual cloud profiles. The below-cloud values are averaged, whenever possible, over $30 \mathrm{~s}$ with a $3 \mathrm{~s}$ gap to the cloud base to avoid issues with time synchronisation across instruments or cloud particle contamination of aerosol probe measurements. This shows that the smallest $r_{\text {eff }}$ are connected to enhanced $\mathrm{rBC}$ concentrations $\left(>10 \mathrm{n} \mathrm{kg}^{-1}\right.$ ) for both sites. Note that for both sites, these high concentrations correspond in each case to a single cloud. However, for OLI there are more enhanced $\mathrm{rBC}$ concentrations $\left(>4 \mathrm{ng} \mathrm{kg}^{-1}\right)$ for intermediate $r_{\text {eff }}$ values $(5-10 \mu \mathrm{m})$ consistent with Fig. 3a. It is interesting to note that this intermediate region is consistent with enhanced local particle concentrations according to HYSPLIT. $\mathrm{rBC}$ can originate from biomass burning as well as anthropogenic sources, but particle size is smaller for the latter (Schwarz et al., 2008). A com- parison of rBC core size (Fig. 9) shows that black carbon particles are generally $50-300 \mathrm{~nm}$ smaller at OLI than at NSA. Together with the collocated enhanced HYSPLIT concentrations, this supports the idea that $\mathrm{rBC}$ measurements around OLI are associated with local emissions from Prudhoe Bay and not transported fire emissions. The coincidence of increased $\mathrm{rBC}$ concentrations with reduced $r_{\mathrm{eff}}$ for OLI might indicate that the observed $\mathrm{rBC}$ acted as a $\mathrm{CCN}$. However this would require the $\mathrm{rBC}$ to be coated with more hygroscopic material (e.g. sulfate), because pure $\mathrm{rBC}$ does not serve as efficient CCN (Weingartner et al., 1997). Note that the SP2 detects the non-coated size of the particles' rBC core, meaning the particles are larger when coated and can potentially act as a CCN despite their small core size.

Similar to Fig. 8, the below-cloud CPC CN concentration is shown in Fig. 10. This figure also indicates an impact of local emissions in the OLI data: $\mathrm{CN}$-observations are enhanced (partly $>1000 \mathrm{~cm}^{-3}$ ) at OLI for all $r_{\mathrm{eff}}$ even though variability is high (compare also Fig. 3b). The $\mathrm{CN}$ observations are dominated by Aitken-mode particles which are typically too small to act as a CCN. This is consistent with the fact that Fig. 10 does not show a correlation between $\mathrm{CN}$ concentration and $r_{\text {eff }}$. Even though the $\mathrm{CN}$ dominating the CPC observations are likely too small to act as $\mathrm{CCN}$, these small particles can grow to accumulation mode quickly given sufficient gaseous precursors, potentially creating a particle population capable of acting as CCN (Jaenicke, 1980).

For the PCASP (Fig. 11), the aerosol concentration is $>100 \mathrm{~cm}^{-3}$ for small $r_{\text {eff }}$ values and $<20 \mathrm{~cm}^{-3}$ for large $r_{\text {eff }}$ values. Note that for NSA, PCASP data corresponding to some of the largest $r_{\text {eff }}$ have been flagged as invalid during quality control and are missing in the figure. The fact that the response of $r_{\text {eff }}$ to PCASP aerosol concentrations is - for constant LWC - almost monotonic for both sites is likely because the PCASP covers the aerosol size range most relevant to droplet nucleation and is consistent with the first indirect 

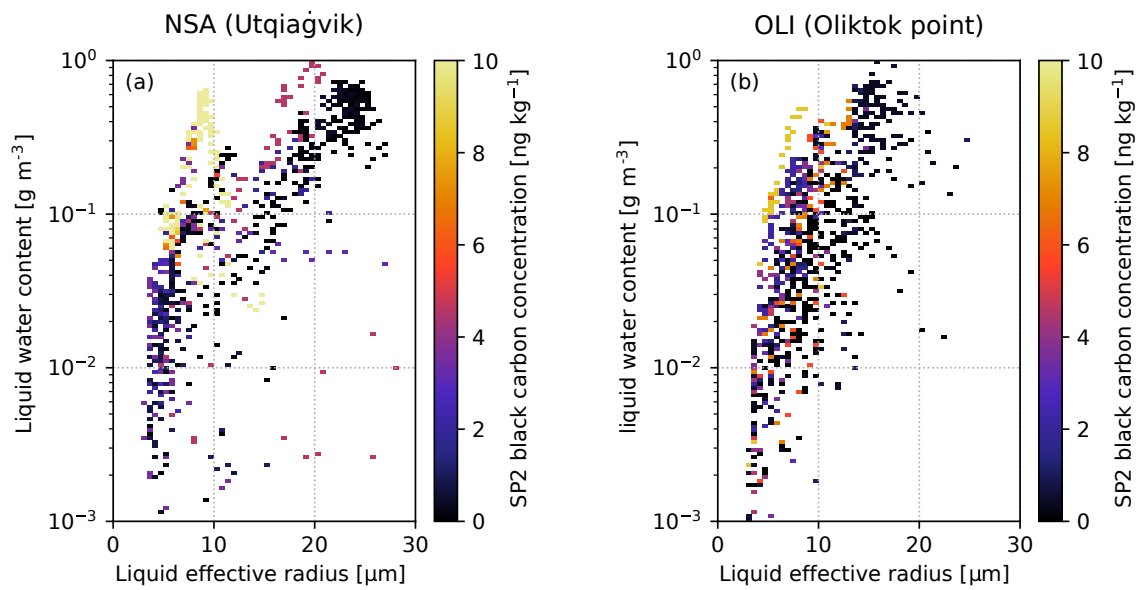

Figure 8. As Fig. 4, but with absolute values for SP2 refractory black carbon rBC concentration for (a) NSA and (b) OLI.
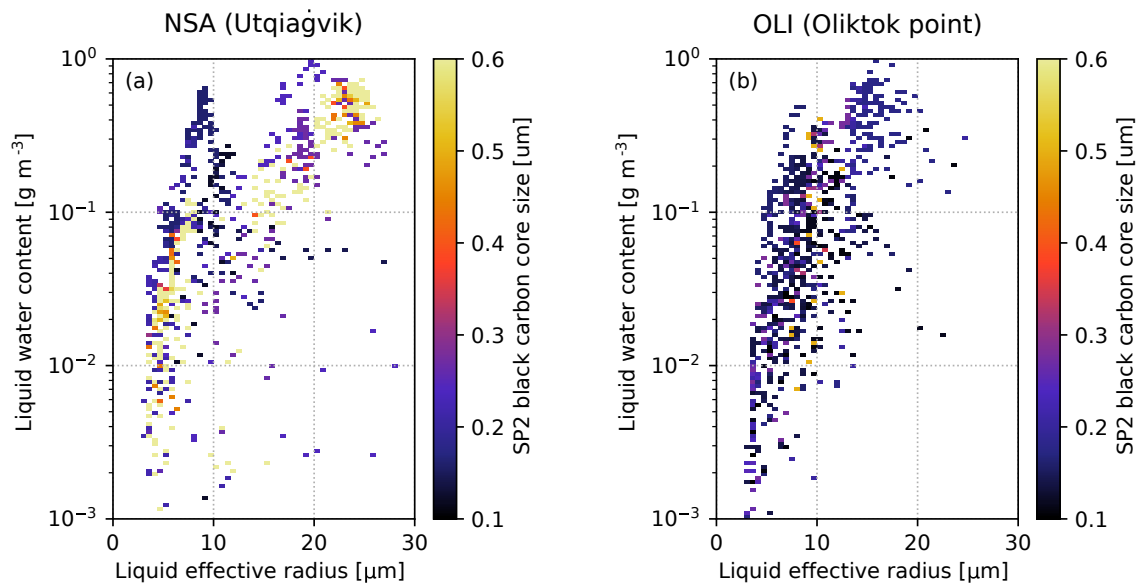

Figure 9. As Fig. 8, but with the mean size of refractory black carbon rBC measured below cloud.

effect. A different behaviour would indicate that clouds react differently to the same PCASP concentration (which covers most of the accumulation-mode size range; see also Sect. 6). However, even though similar PCASP concentrations lead to similar $r_{\text {eff }}$ for both sites, differences still exist relating to the breadth and tail of the distributions, as can be seen from differences in $C$ and $R$ (Fig. 6).

Analysis of the relationship between clouds and HYSPLIT concentrations, $\mathrm{rBC}$ and $\mathrm{CN}$ shows that some, but not all, clouds at OLI are impacted by local pollution. $\mathrm{rBC}$ and $\mathrm{CN}$ concentrations are enhanced in the OLI region (Fig. 3), which is probably related to anthropogenic combustion processes and gas flaring/venting, respectively. Therefore we used these quantities as indicators to isolate clouds impacted by anthropogenic emissions even though there also exist other local sources of small particles (Tunved et al., 2013). Clouds, whose mean below-cloud $\mathrm{rBC}$ or $\mathrm{CN}$ concentration is above the median concentrations shown in Fig. 3 ( $4.1 \mathrm{ng} \mathrm{kg}^{-1}$ and $1122 \mathrm{~cm}^{-3}$, respectively), are identified as potentially impacted. When using this criterion, 10 of 24 (3 of 16) clouds at OLI (NSA) are identified as potentially locally influenced (Fig. 12). For NSA, two of the three clouds corresponded to either extremely low $\mathrm{CN}\left(<20 \mathrm{~cm}^{-3}\right)$ or $\mathrm{rBC}\left(<1 \mathrm{ng} \mathrm{kg}^{-1}\right)$ values, making a connection to anthropogenic activities unlikely. However, the clouds classified as anthropogenic at OLI correspond mostly to enhanced concentrations of $\mathrm{rBC}$ (Fig. 8) and CN (Fig. 10) and mid-sized $r_{\text {eff }}(5-15 \mu \mathrm{m})$. Figure 12 shows how the PCASP concentrations of the potential locally affected clouds compares to the clouds classified as affected by forest fires (these clouds are removed in all other figures except Figs. 12 and 14) and the remaining, non-classified clouds referred to as "other". Note that forest fire emissions were also present in the vicinity of NSA, but cloud measurements from these time periods did not pass the quality control measures implemented (continuously ascending or descending profiles). It is striking that the clouds classified as associated with forest fire have a significant ( $t$ test), 6-fold larger linear mean PCASP concentration than the clouds classified as locally affected at OLI $\left(510\right.$ vs. $\left.80 \mathrm{~cm}^{-3}\right)$. Despite this big difference, clouds 

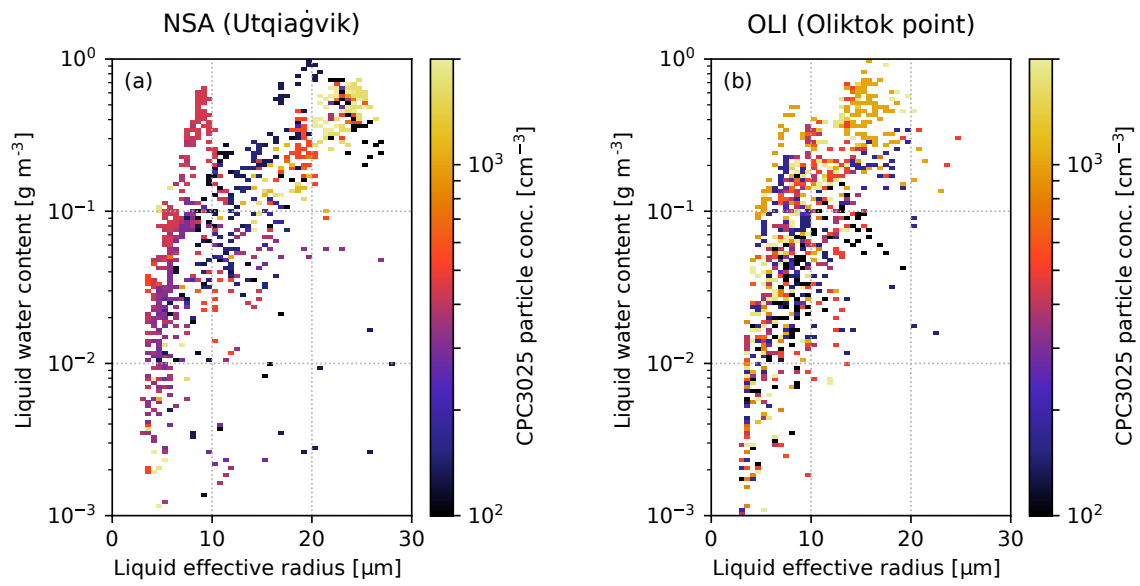

Figure 10. As Fig. 8, but with absolute values for CPC3025 condensation nuclei CN concentration.
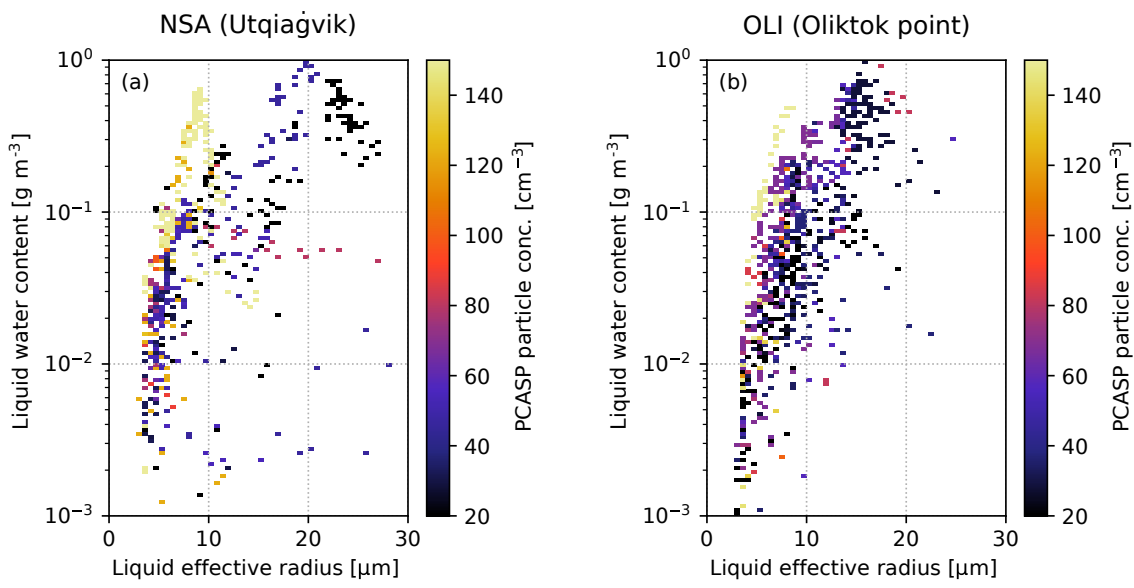

Figure 11. As Fig. 8, but with absolute values for PCASP particle concentration.
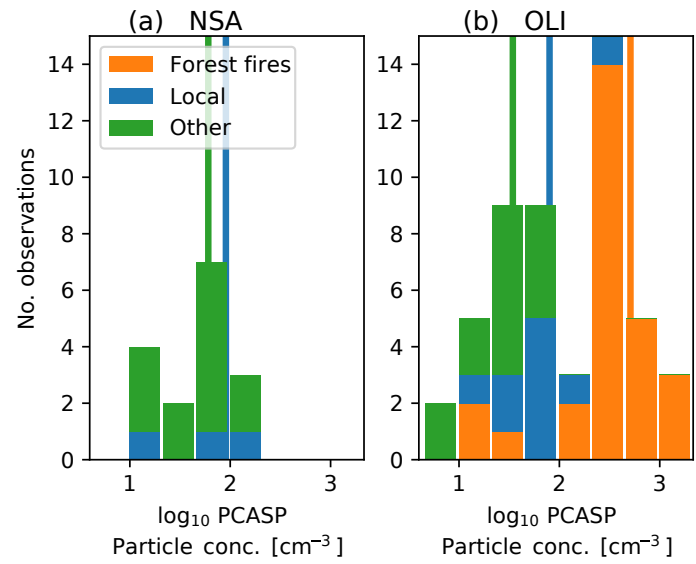

Figure 12. Stacked histograms of PCASP particle concentration for (a) NSA and (b) OLI for clouds classified as forest fire (orange), local (blue), and the residual (green). The vertical lines are for the corresponding linear mean values. classified as locally affected still feature PCASP concentrations significantly larger than the clouds classified as other $\left(35 \mathrm{~cm}^{-3}\right)$. We conclude that $\mathrm{CN}$ and $\mathrm{rBC}$ particles, which were used to classify local clouds, have the potential to grow to accumulation-mode particles measured by the PCASP. For NSA, however, the mean PCASP concentration for clouds classified as other is not significantly $(t$ test) different from the clouds classified as locally affected at OLI. This is also true when including the three clouds classified as locally affected (from which only one is potentially local as discussed above). This is consistent with the findings of Fig. 3, which shows that the general PCASP concentration background is enhanced at NSA in comparison to OLI.

For the clouds classified as locally affected at OLI, the difference in $\mathrm{rBC}, \mathrm{CN}$, and PCASP particle concentration above and below the cloud is presented in Fig. 13. This figure confirms that clouds impacted by local emissions feature higher aerosol concentrations below the cloud than above. This also supports our assumption that below-cloud aerosol properties are most relevant for clouds impacted by anthropogenic 

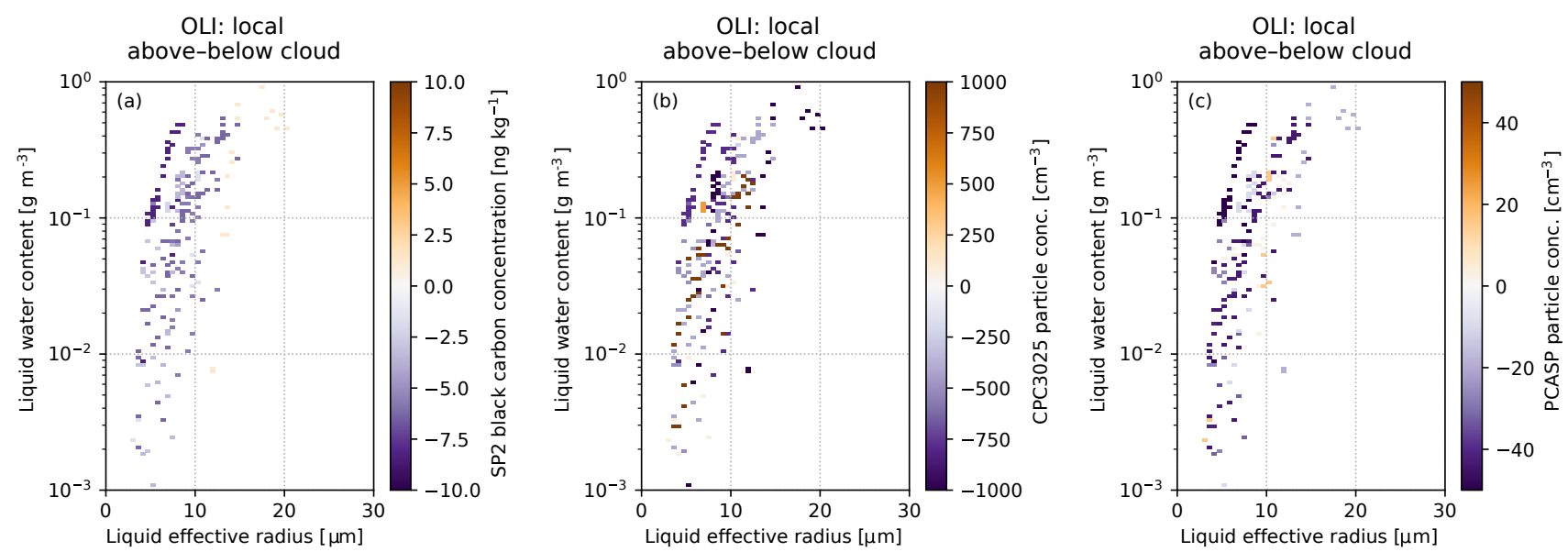

Figure 13. As Figs. 8, 10, and 11 for OLI, but showing the difference of $\mathrm{rBC}(\mathbf{a}), \mathrm{CN}(\mathbf{b})$, and PCASP concentration (c) between observations above and below the clouds classified as locally affected.

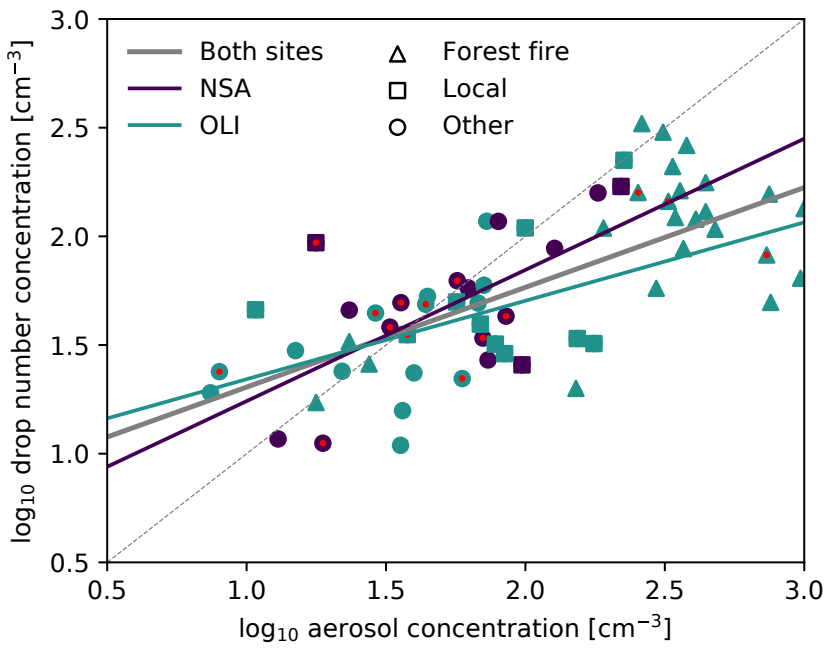

Figure 14. Aerosol indirect effect defined using cloud averaged cloud drop concentration $N_{\text {tot }}$ and PCASP aerosol concentration $N_{\text {a }}$ obtained below cloud. The colours differentiate between OLI (green) and NSA (purple). Clouds classified as anthropogenically impacted, related to forest fires, and remaining other cloud are marked with squares, triangles, and circles, respectively. Red dots indicate clouds where the aerosol concentration above the cloud is higher than below the cloud. The trend lines indicate the linear regressions to obtain ACI (excluding forest fires) for the complete data set (grey), NSA (purple), and OLI (green); the dotted line is the $1: 1$ line.

emissions, which is also true for the remaining anthropogenically influenced cloud at NSA (not shown).

\section{Quantification of aerosol cloud interaction}

Various attempts have been carried out to quantify aerosol cloud interaction (ACI) in Arctic regions (Coopman et al., 2016; Zamora et al., 2016) and its impact on radiation (Earle et al., 2011; Tietze et al., 2011). One common definition used for quantification purposes is

$\mathrm{ACI}=\frac{1}{3} \frac{d \log _{10} N_{\mathrm{tot}}}{d \log _{10} N_{\mathrm{a}}}$,

with $N_{\text {tot }}$ the number concentration of cloud droplets and $N_{\mathrm{a}}$ the number concentration of aerosols (Feingold et al., 2001; McComiskey et al., 2009). For observations, ACI is obtained using a linear regression of $\log _{10} N_{\text {tot }}$ and $\log _{10} N_{\mathrm{a}}$. We prefer defining ACI using $N_{\text {tot }}$ instead of $r_{\text {eff }}$, because the latter varies stronger vertically and would require to classify the clouds by liquid water path, significantly reducing the size of the data set. Figure 14 shows $N_{\text {tot }}$ and $N_{\mathrm{a}}$ for both sites. $N_{\mathrm{a}}$ is obtained from the PCASP because it covers the size range of active accumulation-mode aerosols best. The ACI value for clouds at both sites is $0.14 \pm 0.04$ with $R^{2}=0.30$. Even though $R^{2}$ is small, the ACI value found here is similar to Zamora et al. (2016) who found ACI values of 0.15 for the PCASP using a multi-campaign data set focused on biomass burning. McComiskey and Feingold (2012) found that the choice of platform and observational scales can have a significant impact on the estimation of ACI making comparisons between data sets challenging. Zamora et al. (2016), however, also used cloud-averaged in situ aircraft observations and as a consequence we expect them to be comparable. When applying the linear regression to the data sets corresponding to the two sites separately, the obtained ACI values differ (Table 1), with OLI having a lower ACI value $(0.12 \pm 0.05)$ than NSA $(0.20 \pm 0.07)$. Given the small sample size (24 and 16 cases for OLI and NSA, caused by the PCASP data being quality-flagged for some cases) and the 
Table 1. ACI values for the subsets presented in Fig. 14.

\begin{tabular}{lccc}
\hline Data set & ACI & $R^{2}$ & No. of clouds \\
\hline Both sites & $0.14 \pm 0.04$ & 0.30 & 40 \\
OLI & $0.12 \pm 0.05$ & 0.24 & 24 \\
NSA & $0.20 \pm 0.07$ & 0.40 & 16 \\
\hline Both sites (with fires) & $0.14 \pm 0.02$ & 0.47 & 67 \\
OLI (with fires) & $0.14 \pm 0.02$ & 0.48 & 51 \\
\hline
\end{tabular}

overlap of the uncertainty ranges (obtained from the linear regression), it is not possible to determine whether there is a difference in aerosols' nucleation efficiency between the two sites. In addition, given the small sample size, we did not estimate ACI for local clouds only. The lower $R^{2}$ value for OLI (0.24) in comparison to NSA (0.40) could indicate that the assumption that PCASP particle concentrations represent a good approximation for $\mathrm{CCN}$ concentrations is partly violated at OLI. This is consistent with those particles being less aged and consequently less coated by sulfates and organics in comparison to those observed around NSA, though detailed observations of chemical composition were not available for this campaign. In addition, some data points lie above the $1: 1$ line in Fig. 14, which might indicate that particles smaller than the PCASP size range (i.e. $<100 \mathrm{~nm}$ ) are acting as CCN (Leaitch et al., 2016). Further, the assumption that the below-cloud aerosol properties govern the cloud microphysical properties might not be true for all clouds depending on sub-cloud vertical mixing. Therefore, we identified all clouds where the above-cloud PCASP concentration is larger than below-cloud (red dots in Fig. 14), and indeed half of these clouds are above the $1: 1$ line. When using the above-cloud concentration for these clouds, only two of these clouds are above the $1: 1$ line. However, there are still 11 more clouds above the $1: 1$ line. Since these clouds generally feature PCASP concentrations $<50 \mathrm{~cm}^{-3}$, the fact that they are above the $1: 1$ line could be related to increasing sampling errors for small concentrations but might also be related to activation of aerosols below $100 \mathrm{~nm}$ diameter (Leaitch et al., 2016).

For comparison, we also evaluate ACI calculated including data points associated with forest fires. Based on the flight patterns executed, all of the cloud measurements associated with forest fire emissions were sampled in the vicinity of OLI as discussed above. For the measurements collected, aerosols associated with forest fires generally feature higher PCASP concentrations (and in consequence smaller $r_{\text {eff }}$ ), which is consistent with ageing of these particles during transport and in contrast to the freshly emitted particles generally found around OLI. As already discussed, clouds associated with local emissions have lower PCASP (and likely accumulation mode) concentrations than forest fires but still have larger concentrations than for the other clouds. When including cases associated with forest fire emissions, ACI is found to be $0.14 \pm 0.02$ for both OLI and the complete data set and is similar to results obtained when omitting forest fire influenced cases. Therefore, we conclude that a difference in ACI between local emissions and forest fires cannot be found, given the limited data set. This refers only to the mechanisms through which aerosols change cloud properties and does not imply that local emissions do not change cloud properties.

\section{Conclusions}

The impact of local emissions from industrial activities in northern Alaska on liquid clouds has been investigated based on vertical profiles of aerosol and cloud properties during the ACME-V aircraft campaign, together with measurements from the ARM sites in northern Alaska: Oliktok Point (OLI) and Utqiagivik (formerly known as Barrow or ARM's North Slope of Alaska site, NSA). Our main findings can be summarised as follows:

1. Concentrations of condensation nuclei $(\mathrm{CN})$ and refractory black carbon ( $\mathrm{rBC})$ are higher in the OLI area (Fig. 3). This is related to emissions associated with local oil and natural gas extraction activities. In contrast, PCASP particle concentrations (diameter $>$ $100 \mathrm{~nm}$, mostly accumulation mode) are not elevated around OLI when compared to NSA.

2. In addition, we found (Fig. 4) that liquid clouds generally feature significantly smaller $r_{\text {eff }}$ at OLI when compared with NSA for LWC $>0.1 \mathrm{~g} \mathrm{~kg}^{-1}$. Clouds with $r_{\text {eff }}>18 \mu \mathrm{m}$ are only rarely observed at OLI. Furthermore, collision-coalescence and precipitation rates are reduced by up to 2 orders of magnitude around OLI (Fig. 6). Only half of this reduction can be explained by the reduced $r_{\text {eff. }}$ As a consequence, the breadth of the size distribution of liquid droplets is smaller at OLI as was observed (Fig. 5b). The reduction of $r_{\text {eff }}$ at OLI occurs despite the larger background of PCASP concentrations at NSA (Fig. 3c)

3. Multiple lines of evidence connect these changes in cloud properties to the observed local emissions. First, HYSPLIT simulations show that $50 \%$ of all cloud observations around OLI can be traced back to local emission sources (Fig. 7). Second, some clouds with midsize $r_{\text {eff }}$ (between 9 and $12 \mu \mathrm{m}$ ) at OLI correspond to increased $\mathrm{CN}$ and $\mathrm{rBC}$ concentrations (Figs. 8 and 10). Third, the mean size of cloud-associated $\mathrm{rBC}$ particles is smaller at OLI which is consistent with the assumption of anthropogenic sources (Fig. 9). Finally, the clouds identified as most likely influenced by anthropogenic activities have significantly higher PCASP concentrations for OLI than for the remaining clouds (Fig. 12). However, the PCASP concentration of local clouds is 
not significantly higher than at NSA, which might be related to a higher background of PCASP particle concentrations at NSA.

4. Given the limited data set, we found 10 of 24 clouds at OLI, but only 1 of 16 clouds at NSA which might be impacted by local anthropogenic emissions.

5. The PCASP concentration of clouds associated with forest fires is on average 6 times larger than for locally impacted clouds (Fig. 12). Consequently, the impact of local emissions on cloud properties is small compared to the influence of forest fires (Fig. 14).

6. Quantification of aerosol cloud interaction (ACI) is challenging due to the small data set. Having said this, based on evaluation of clouds impacted by both local emissions and forest fires, the results are consistent with previous studies of ACI in the Arctic environment (Fig. 14). While forest fire cases have typically higher PCASP concentrations and consequently droplet concentrations, their inclusion in the estimation of ACI does not substantially alter the found relationship.

Because liquid clouds were observed most often $(60 \%)$, the impact of local pollution on mixed-phase and pure ice clouds is not covered here. Moreover, the question as to what percentage of clouds at OLI (and NSA) is impacted by local emissions and whether the industrial activities at the North Slope of Alaska also lead to a change in local climate (e.g. due to cloud radiative forcing, precipitation impacts, or cloud life cycle) cannot be answered with in situ aircraft measurements alone. These questions can likely better be answered using ground- and satellite-based remote sensing data from OLI and NSA by identifying differences between the sites in cloud cover, liquid water path, emissivity, effective droplet size, and precipitation occurrence. Nevertheless, based on this limited in situ data set we can conclude that local emissions form industrial facilities in Alaska do influence local cloud properties, while the overall spatial extent of these influences has yet to be evaluated. Given the observed cloud modifications, the effects of anthropogenic pollution on local climate should be considered when developing industrial infrastructure in an already fragile and warming Arctic environment.

Data availability. Data were obtained from the Atmospheric Radiation Measurement (ARM) climate research facility, a US Department of Energy Office of Science user facility sponsored by the Office of Biological and Environmental Research. The surface observations from OLI and NSA as well as the ACME-V data set are available at the ARM archive www.arm.gov/data (see ARM, 1993, 2016). The phase classification of the cloud probes is available from the corresponding author on request.
Competing interests. The authors declare that they have no conflict of interest.

Acknowledgements. The authors would like to thank the teams of the ARM facilities (aerial, Oliktok Point, Utqiagivik/Barrow) and the team responsible for processing and providing the data of the ACME-V campaign: among others, Sebastien Biraud, Duli Chand, Connor Flynn, John Hubbe, Charles N. Long, Alyssa Matthews, Mikhail Pekour, Beat Schmid, Arthur J. Sedlacek, Stephen Springston, and Jason Tomlinson. Contributions from Maximilian Maahn, Gijs de Boer, and Jessie M. Creamean were supported by the US Department of Energy Atmospheric System Research (DOE ASR) programme under award number DE-SC0013306. Gijs de Boer was additionally supported by NSF project ARC 1203902. Graham Feingold was supported under DOE ASR grant no. DE-SC0016275; Greg M. McFarquhar and Wei Wu were supported under DOE ASR grant no. DE-SC0016476 (through UCAR subcontract Z17-90029). The authors gratefully acknowledge the NOAA Air Resources Laboratory (ARL) for the provision of the HYSPLIT transport and dispersion model used in this publication. We thank the editor and the two anonymous reviewers for their helpful comments. We also acknowledge valuable discussions with Franziska Glassmeier and the helpful comments of the anonymous reviewers.

Edited by: Xiaohong Liu

Reviewed by: three anonymous referees

\section{References}

Albrecht, B. A.: Aerosols, cloud microphysics, and fractional cloudiness, Science, 245, 1227-1230, https://doi.org/10.1126/science.245.4923.1227, 1989.

ARM: Atmospheric Radiation Measurement (ARM) Climate Research Facility standard Meteorological Instrumentation at Surface (NSAMET and OLIMET). Jun. 2015-Sep. 2015, $71^{\circ} 19^{\prime} 22.8^{\prime \prime} \mathrm{N}, 156^{\circ} 36^{\prime} 32.4^{\prime \prime} \mathrm{W}$ : North Slope of Alaska Central Facility (C1) and $70^{\circ} 29^{\prime} 42^{\prime \prime} \mathrm{N}, 149^{\circ} 53^{\prime} 9.6^{\prime \prime} \mathrm{W}$ : Oliktok Mobile Facility (M1). Compiled by Donna Holdridge and Jenni Kyrouac. ARM Data Archive, Oak Ridge National Laboratory (ORNL), Oak Ridge, TN, USA. Data set accessed: 23 March 2016, https://doi.org/10.5439/1025220, 1993 (updated daily).

ARM: Atmospheric Radiation Measurement Climate Research Facility Campaign datasets for ARM Airborne Carbon Measurements (ARM-ACME-V). Jun. 2015-Sep. 2015, ARM Aerial Facility. Compiled by Sebastien Biraud, Fan Mei, Connor Flynn, John Hubbe, Chuck Long, Alyssa Matthews, Mikhail Pekour, Arthur Sedlacek, Stephen Springston, Jason Tomlinson, and Duli Chand. ARM Data Archive, Oak Ridge National Laboratory (ORNL), Oak Ridge, TN, USA. Data set accessed: 23 March 2016, https://doi.org/10.5439/1346549, 2016.

Biraud, S. C.: ARM-ACME V: ARM Airborne Carbon Measurements V on the North Slope of Alaska Field Campaign Report, Tech. Rep., DOE Office of Science Atmospheric Radiation Measurement (ARM) Program (United States), available at: https://www.arm.gov/publications/programdocs/ doe-sc-arm-16-031.pdf, 2016. 
Bond, T. C., Streets, D. G., Yarber, K. F., Nelson, S. M., Woo, J.-H., and Klimont, Z.: A technology-based global inventory of black and organic carbon emissions from combustion, J. Geophys. Res.-Atmos., 109, D14203, https://doi.org/10.1029/2003JD003697, 2004.

Bond, T. C., Doherty, S. J., Fahey, D. W., Forster, P. M., Berntsen, T., DeAngelo, B. J., Flanner, M. G., Ghan, S., Kärcher, B., Koch, D., Kinne, S., Kondo, Y., Quinn, P. K., Sarofim, M. C., Schultz, M. G., Schulz, M., Venkataraman, C., Zhang, H., Zhang, S., Bellouin, N., Guttikunda, S. K., Hopke, P. K., Jacobson, M. Z., Kaiser, J. W., Klimont, Z., Lohmann, U., Schwarz, J. P., Shindell, D., Storelvmo, T., Warren, S. G., and Zender, C. S.: Bounding the role of black carbon in the climate system: a scientific assessment, J. Geophys. Res.-Atmos., 118, 5380-5552, https://doi.org/10.1002/jgrd.50171, 2013.

Brock, C. A., Cozic, J., Bahreini, R., Froyd, K. D., Middlebrook, A. M., McComiskey, A., Brioude, J., Cooper, O. R., Stohl, A., Aikin, K. C., de Gouw, J. A., Fahey, D. W., Ferrare, R. A., Gao, R.-S., Gore, W., Holloway, J. S., Hübler, G., Jefferson, A., Lack, D. A., Lance, S., Moore, R. H., Murphy, D. M., Nenes, A., Novelli, P. C., Nowak, J. B., Ogren, J. A., Peischl, J., Pierce, R. B., Pilewskie, P., Quinn, P. K., Ryerson, T. B., Schmidt, K. S., Schwarz, J. P., Sodemann, H., Spackman, J. R., Stark, H., Thomson, D. S., Thornberry, T., Veres, P., Watts, L. A., Warneke, C., and Wollny, A. G.: Characteristics, sources, and transport of aerosols measured in spring 2008 during the aerosol, radiation, and cloud processes affecting Arctic Climate (ARCPAC) Project, Atmos. Chem. Phys., 11, 2423 2453, https://doi.org/10.5194/acp-11-2423-2011, 2011.

Cai, Y., Snider, J. R., and Wechsler, P.: Calibration of the passive cavity aerosol spectrometer probe for airborne determination of the size distribution, Atmos. Meas. Tech., 6, 2349-2358, https://doi.org/10.5194/amt-6-2349-2013, 2013.

Colbeck, I. and Lazaridis, M.: Aerosol Science: Technology and Applications, John Wiley \& Sons, Chichester, UK, 2014.

Colman, R.: A comparison of climate feedbacks in general circulation models, Clim. Dynam., 20, 865-873, https://doi.org/10.1007/s00382-003-0310-z, 2003.

Coopman, Q., Garrett, T. J., Riedi, J., Eckhardt, S., and Stohl, A.: Effects of long-range aerosol transport on the microphysical properties of low-level liquid clouds in the Arctic, Atmos. Chem. Phys., 16, 4661-4674, https://doi.org/10.5194/acp16-4661-2016, 2016.

Creamean, J. M., Maahn, M., de Boer, G., McComiskey, A., Sedlacek, A. J., and Feng, Y.: The influence of local oil exploration, regional wildfires, and long range transport on summer 2015 aerosol over the North Slope of Alaska, Atmos. Chem. Phys. Discuss., https://doi.org/10.5194/acp-2017-594, in review, 2017.

Croft, B., Wentworth, G. R., Martin, R. V., Leaitch, W. R., Murphy, J. G., Murphy, B. N., Kodros, J. K., Abbatt, J. P. D., and Pierce, J. R.: Contribution of Arctic seabird-colony ammonia to atmospheric particles and cloud-albedo radiative effect, Nat. Commun., 7, 13444, https://doi.org/10.1038/ncomms13444, 2016.

Dolgos, G. and Martins, J. V.: Polarized Imaging Nephelometer for in situ airborne measurements of aerosol light scattering, Opt. Express, 22, 21972-21990, 2014.

Earle, M. E., Liu, P. S. K., Strapp, J. W., Zelenyuk, A., Imre, D., McFarquhar, G. M., Shantz, N. C., and Leaitch, W. R.: Factors influencing the microphysics and radiative properties of liquid-dominated Arctic clouds: insight from observations of aerosol and clouds during ISDAC, J. Geophys. Res.-Atmos., 116, D00T09, https://doi.org/10.1029/2011JD015887, 2011.

Eck, T. F., Holben, B. N., Reid, J. S., Dubovik, O., Smirnov, A., O'Neill, N. T., Slutsker, I., and Kinne, S.: Wavelength dependence of the optical depth of biomass burning, urban, and desert dust aerosols, J. Geophys. Res.-Atmos., 104, 3133331349, https://doi.org/10.1029/1999JD900923, 1999.

Feingold, G. and Siebert, H.: Cloud-aerosol interactions from the micro to the cloud scale, in: Strüngmann Forum Report, edited by: Heintzenberg, J. and Charlson, R. J., The MIT Press, Cambridge, MA, 2009.

Feingold, G., Kreidenweis, S. M., Stevens, B., and Cotton, W. R.: Numerical simulations of stratocumulus processing of cloud condensation nuclei through collisioncoalescence, J. Geophys. Res.-Atmos., 101, 21391-21402, https://doi.org/10.1029/96JD01552, 1996.

Feingold, G., Remer, L. A., Ramaprasad, J., and Kaufman, Y. J.: Analysis of smoke impact on clouds in Brazilian biomass burning regions: an extension of Twomey's approach, J. Geophys. Res.-Atmos., 106, 22907-22922, https://doi.org/10.1029/2001JD000732, 2001.

Garrett, T. J. and Zhao, C.: Increased Arctic cloud longwave emissivity associated with pollution from mid-latitudes, Nature, 440, 787-789, https://doi.org/10.1038/nature04636, 2006.

Garrett, T. J., Zhao, C., Dong, X., Mace, G. G., and Hobbs, P. V.: Effects of varying aerosol regimes on lowlevel Arctic stratus, Geophys. Res. Lett., 31, L17105, https://doi.org/10.1029/2004GL019928, 2004.

Gautier, D. L., Bird, K. J., Charpentier, R. R., Grantz, A., Houseknecht, D. W., Klett, T. R., Moore, T. E., Pitman, J. K., Schenk, C. J., Schuenemeyer, J. H., Sørensen, K., Tennyson, M. E., Valin, Z. C., and Wandrey, C. J.: Assessment of undiscovered oil and gas in the Arctic, Science, 324, 1175-1179, https://doi.org/10.1126/science.1169467, 2009.

Gerber, H.: Microphysics of marine stratocumulus clouds with two drizzle modes, J. Atmos. Sci., 53, 1649-1662, https://doi.org/10.1175/15200469(1996)053<1649:MOMSCW>2.0.CO;2, 1996.

Giglio, L.: MODIS Collection 5 Active Fire Product User's Guide Version 2.5, available at: http://modis-fire.umd.edu/files/ MODIS_Fire_Users_Guide_2.5.pdf, 2013.

Giglio, L., Descloitres, J., Justice, C. O., and Kaufman, Y. J.: An enhanced contextual fire detection algorithm for MODIS, Remote Sens. Environ., 87, 273-282, https://doi.org/10.1016/S00344257(03)00184-6, 2003.

Gunn, R. and Phillips, B. B.: An experimental investigation of the effect of air pollution on the initiation of rain, J. Meteorol., 14, 272-280, https://doi.org/10.1175/15200469(1957)014<0272:AEIOTE>2.0.CO;2, 1957.

Gysel, M., Laborde, M., Olfert, J. S., Subramanian, R., and Gröhn, A. J.: Effective density of Aquadag and fullerene soot black carbon reference materials used for SP2 calibration, Atmos. Meas. Tech., 4, 2851-2858, https://doi.org/10.5194/amt-4-2851-2011, 2011.

Hermann, M., Wehner, B., Bischof, O., Han, H. S., Krinke, T., Liu, W., Zerrath, A., and Wiedensohler, A.: Particle counting efficiencies of new TSI condensation particle counters, J. Aerosol Sci., 
38, 674-682, https://doi.org/10.1016/j.jaerosci.2007.05.001, 2007.

Hobbs, P. V. and Rangno, A. L.: Microstructures of low and middlelevel clouds over the Beaufort Sea, Q. J. Roy. Meteor. Soc., 124, 2035-2071, https://doi.org/10.1002/qj.49712455012, 1998.

Holroyd, E. W.: Some techniques and uses of 2D-C habit classification software for snow particles, J. Atmos. Ocean. Tech., 4, 498-511, https://doi.org/10.1175/15200426(1987)004<0498:STAUOC>2.0.CO;2, 1987.

Intrieri, J. M., Fairall, C. W., Shupe, M. D., Persson, P. O. G., Andreas, E. L., Guest, P. S., and Moritz, R. E.: An annual cycle of Arctic surface cloud forcing at SHEBA, J. Geophys. Res.-Atmos., 107, 8039, https://doi.org/10.1029/2000JC000439, 2002.

Irwin, M., Kondo, Y., Moteki, N., and Miyakawa, T.: Evaluation of a Heated-Inlet for calibration of the SP2, Aerosol Sci. Tech., 47, 895-905, 2013.

Jackson, R. C., McFarquhar, G. M., Korolev, A. V., Earle, M. E., Liu, P. S. K., Lawson, R. P., Brooks, S., Wolde, M., Laskin, A., and Freer, M.: The dependence of ice microphysics on aerosol concentration in arctic mixed-phase stratus clouds during ISDAC and M-PACE, J. Geophys. Res.-Atmos., 117, D15207, https://doi.org/10.1029/2012JD017668, 2012.

Jaenicke, R.: Atmospheric aerosols and global climate, J. Aerosol Sci., 11, 577-588, https://doi.org/10.1016/0021-8502(80)901317, 1980.

Jeffries, M., Overland, J., and Perovich, D.: The Arctic shifts to a new normal, Phys. Today, 66, 35-40, https://doi.org/10.1063/PT.3.2147, 2013.

Kalnay, E., Kanamitsu, M., Kistler, R., Collins, W., Deaven, D., Gandin, L., Iredell, M., Saha, S., White, G., Woollen, J., Zhu, Y., Chelliah, M., Ebisuzaki, W., Higgins, W., Janowiak, J., Mo, K. C., Ropelewski, C., Wang, J., Leetmaa, A., Reynolds, R., Jenne, R., and Joseph, D.: The NCEP/NCAR 40-year reanalysis project, B. Am. Meteorol. Soc., 77, 437-471, 1996.

Kassianov, E., Berg, L. K., Pekour, M., Barnard, J., Chand, D., Flynn, C., Ovchinnikov, M., Sedlacek, A., Schmid, B., Shilling, J., Tomlinson, J., and Fast, J.: Airborne aerosol in situ measurements during TCAP: a closure study of total scattering, Atmosphere, 6, 1069-1101, https://doi.org/10.3390/atmos6081069, 2015.

Khvorostyanov, V. I. and Curry, J. A.: Terminal velocities of droplets and crystals: power laws with continuous parameters over the size spectrum, J. Atmos. Sci., 59, 1872-1884, https://doi.org/10.1175/15200469(2002)059<1872:TVODAC>2.0.CO;2, 2002.

King, W. D., Parkin, D. A., and Handsworth, R. J.: A hot-wire liquid water device having fully calculable response characteristics, J. Appl. Meteorol., 17, 1809-1813, https://doi.org/10.1175/15200450(1978)017<1809:AHWLWD>2.0.CO;2, 1978.

King, W. D., Maher, C. T., and Hepburn, G. A.: Further performance tests on the CSIRO liquid water probe, J. Appl. Meteorol., 20, 195-202, 1981.

King, W. D., Dye, J. E., Baumgardner, D., Strapp, J. W., and Huffman, D.: Icing wind tunnel tests on the CSIRO liquid water probe, J. Atmos. Ocean. Tech., 2, 340-352, 1985.

Kolesar, K. R., Cellini, J., Peterson, P. K., Jefferson, A., Tuch, T., Birmili, W., Wiedensohler, A., and Pratt, K. A.: Effect of Prudhoe Bay emissions on atmospheric aerosol growth events observed in Utqiaġvik (Barrow), Alaska, Atmos. Environ., 152, 146-155, https://doi.org/10.1016/j.atmosenv.2016.12.019, 2017.

Kondo, Y., Matsui, H., Moteki, N., Sahu, L., Takegawa, N., Kajino, M., Zhao, Y., Cubison, M. J., Jimenez, J. L., Vay, S., Diskin, G. S., Anderson, B., Wisthaler, A., Mikoviny, T., Fuelberg, H. E., Blake, D. R., Huey, G., Weinheimer, A. J., Knapp, D. J., and Brune, W. H.: Emissions of black carbon, organic, and inorganic aerosols from biomass burning in North America and Asia in 2008, J. Geophys. Res.-Atmos., 116, D08204, https://doi.org/10.1029/2010JD015152, 2011.

Korolev, A. V., Kuznetsov, S. V., Makarov, Y. E., and Novikov, V. S.: Evaluation of measurements of particle size and sample area from optical array probes, J. Atmos. Ocean. Tech., 8, 514-522, https://doi.org/10.1175/15200426(1991)008<0514:EOMOPS>2.0.CO;2, 1991.

Kulmala, M., Petäjä, T., Nieminen, T., Sipilä, M., Manninen, H. E., Lehtipalo, K., Dal Maso, M., Aalto, P. P., Junninen, H., Paasonen, P., Riipinen, I., Lehtinen, K. E. J., Laaksonen, A., and Kerminen, V.-M.: Measurement of the nucleation of atmospheric aerosol particles, Nat. Protoc., 7, 1651-1667, https://doi.org/10.1038/nprot.2012.091, 2012.

Lack, D. A., Moosmüller, H., McMeeking, G. R., Chakrabarty, R. K., and Baumgardner, D.: Characterizing elemental, equivalent black, and refractory black carbon aerosol particles: a review of techniques, their limitations and uncertainties, Anal. Bioanal. Chem., 406, 99-122, https://doi.org/10.1007/s00216-013-74023, 2014.

Lance, S., Brock, C. A., Rogers, D., and Gordon, J. A.: Water droplet calibration of the Cloud Droplet Probe (CDP) and in-flight performance in liquid, ice and mixed-phase clouds during ARCPAC, Atmos. Meas. Tech., 3, 1683-1706, https://doi.org/10.5194/amt-3-1683-2010, 2010.

Lance, S., Shupe, M. D., Feingold, G., Brock, C. A., Cozic, J., Holloway, J. S., Moore, R. H., Nenes, A., Schwarz, J. P., Spackman, J. R., Froyd, K. D., Murphy, D. M., Brioude, J., Cooper, O. R., Stohl, A., and Burkhart, J. F.: Cloud condensation nuclei as a modulator of ice processes in Arctic mixed-phase clouds, Atmos. Chem. Phys., 11, 8003-8015, https://doi.org/10.5194/acp11-8003-2011, 2011.

Law, K. S. and Stohl, A.: Arctic air pollution: origins and impacts, Science, 315, 1537-1540, https://doi.org/10.1126/science.1137695, 2007.

Lawson, R. P., Stewart, R. E., Strapp, J. W., and Isaac, G. A.: Aircraft observations of the origin and growth of very large snowflakes, Geophys. Res. Lett., 20, 53-56, https://doi.org/10.1029/92GL02917, 1993.

Lawson, R. P., O’Connor, D., Zmarzly, P., Weaver, K., Baker, B., Mo, Q., and Jonsson, H.: The 2D-S (stereo) probe: design and preliminary tests of a new airborne, high-speed, high-resolution particle imaging probe, J. Atmos. Ocean. Tech., 23, 1462-1477, https://doi.org/10.1175/JTECH1927.1, 2006.

Leaitch, W. R., Isaac, G. A., Strapp, J. W., Banic, C. M., and Wiebe, H. A.: The relationship between cloud droplet number concentrations and anthropogenic pollution: observations and climatic implications, J. Geophys. Res.-Atmos., 97, 2463-2474, https://doi.org/10.1029/91JD02739, 1992.

Leaitch, W. R., Korolev, A., Aliabadi, A. A., Burkart, J., Willis, M. D., Abbatt, J. P. D., Bozem, H., Hoor, P., Köllner, F., Schneider, J., Herber, A., Konrad, C., and Brauner, R.: Ef- 
fects of $20-100 \mathrm{~nm}$ particles on liquid clouds in the clean summertime Arctic, Atmos. Chem. Phys., 16, 11107-11124, https://doi.org/10.5194/acp-16-11107-2016, 2016.

Long, A. B.: Solutions to the droplet collection equation for polynomial kernels, J. Atmos. Sci., 31, 1040-1052, https://doi.org/10.1175/15200469(1974)031<1040:STTDCE>2.0.CO;2, 1974.

Massey Jr., F. J.: The Kolmogorov-Smirnov test for goodness of fit, J. Am. Stat. Assoc., 46, 68-78, https://doi.org/10.2307/2280095, 1951.

Matsui, H., Kondo, Y., Moteki, N., Takegawa, N., Sahu, L. K., Zhao, Y., Fuelberg, H. E., Sessions, W. R., Diskin, G., Blake, D. R., Wisthaler, A., and Koike, M.: Seasonal variation of the transport of black carbon aerosol from the Asian continent to the Arctic during the ARCTAS aircraft campaign, J. Geophys. Res.-Atmos., 116, D05202, https://doi.org/10.1029/2010JD015067, 2011.

McComiskey, A. and Feingold, G.: The scale problem in quantifying aerosol indirect effects, Atmos. Chem. Phys., 12, 1031-1049, https://doi.org/10.5194/acp-12-1031-2012, 2012.

McComiskey, A., Feingold, G., Frisch, A. S., Turner, D. D., Miller, M. A., Chiu, J. C., Min, Q., and Ogren, J. A.: An assessment of aerosol-cloud interactions in marine stratus clouds based on surface remote sensing, J. Geophys. Res.-Atmos., 114, D09203, https://doi.org/10.1029/2008JD011006, 2009.

McFarquhar, G., Ghan, S. J., Verlinde, J., Korolev, A., Strapp, J. W., Schmid, B., Tomlinson, J. M., Wolde, M., Brooks, S. D., Cziczo, D. J., Dubey, M. K., Fan, J., Flynn, C. J., Gultepe, I., Hubbe, J. M., Gilles, M. K., Laskin, A., Lawson, P., Leaitch, W. R., Liu, P. S., Liu, X., Lubin, D., Mazzoleni, C., Macdonald, A. M., Moffet, R. C., Morrison, H., Ovchinnikov, M., Shupe, M. D., Turner, D. D., Xie, S., Zelenyuk, A., Bae, K., Freer, M., and Glen, A.: Indirect and semi-direct aerosol campaign: the impact of Arctic aerosols on clouds, B. Am. Meteorol. Soc., 92, 183-201, https://doi.org/10.1175/2010BAMS2935.1, 2011.

Mordas, G., Manninen, H. E., Petäjä, T., Aalto, P. P., Hämeri, K., and Kulmala, M.: On operation of the ultra-fine water-based CPC TSI 3786 and comparison with other TSI models (TSI 3776, TSI 3772, TSI 3025, TSI 3010, TSI 3007), Aerosol Sci. Tech., 42, 152-158, https://doi.org/10.1080/02786820701846252, 2008.

Ødemark, K., Dalsøren, S. B., Samset, B. H., Berntsen, T. K., Fuglestvedt, J. S., and Myhre, G.: Short-lived climate forcers from current shipping and petroleum activities in the Arctic, Atmos. Chem. Phys., 12, 1979-1993, https://doi.org/10.5194/acp12-1979-2012, 2012.

Peters, G. P., Nilssen, T. B., Lindholt, L., Eide, M. S., Glomsrød, S., Eide, L. I., and Fuglestvedt, J. S.: Future emissions from shipping and petroleum activities in the Arctic, Atmos. Chem. Phys., 11, 5305-5320, https://doi.org/10.5194/acp-11-5305-2011, 2011.

Platnick, S. and Twomey, S.: Remote sensing the susceptibility of cloud albedo to changes in drop concentration, Atmos. Res., 34, 85-98, https://doi.org/10.1016/0169-8095(94)90082-5, 1994.

Pruppacher, H. R. and Klett, J. D.: Microphysics of Clouds and Precipitation, 2nd Ed., Springer, Dordrecht, 2010.

Quinn, P. K., Miller, T. L., Bates, T. S., Ogren, J. A., Andrews, E., and Shaw, G. E.: A 3-year record of simultaneously measured aerosol chemical and optical properties at Barrow, Alaska, J. Geophys. Res.-Atmos., 107, AAC 8-1, https://doi.org/10.1029/2001JD001248, 2002.
Quinn, P. K., Bates, T. S., Schulz, K., and Shaw, G. E. Decadal trends in aerosol chemical composition at Barrow, Alaska: 1976-2008, Atmos. Chem. Phys., 9, 8883-8888, https://doi.org/10.5194/acp-9-8883-2009, 2009.

Rissler, J., Vestin, A., Swietlicki, E., Fisch, G., Zhou, J., Artaxo, P., and Andreae, M. O.: Size distribution and hygroscopic properties of aerosol particles from dry-season biomass burning in Amazonia, Atmos. Chem. Phys., 6, 471-491, https://doi.org/10.5194/acp-6-471-2006, 2006.

Roiger, A., Thomas, J.-L., Schlager, H., Law, K. S., Kim, J., Schäfler, A., Weinzierl, B., Dahlkötter, F., Krisch, I., Marelle, L., Minikin, A., Raut, J.-C., Reiter, A., Rose, M., Scheibe, M., Stock, P., Baumann, R., Bouarar, I., Clerbaux, C., George, M., Onishi, T., and Flemming, J.: Quantifying emerging local anthropogenic emissions in the Arctic region: the ACCESS Aircraft Campaign Experiment, B. Am. Meteorol. Soc., 96, 441460, https://doi.org/10.1175/BAMS-D-13-00169.1, 2015.

Sakamoto, K. M., Allan, J. D., Coe, H., Taylor, J. W., Duck, T. J., and Pierce, J. R.: Aged boreal biomass-burning aerosol size distributions from BORTAS 2011, Atmos. Chem. Phys., 15, 16331646, https://doi.org/10.5194/acp-15-1633-2015, 2015.

Schmid, B., Tomlinson, J. M., Hubbe, J. M., Comstock, J. M., Mei, F., Chand, D., Pekour, M. S., Kluzek, C. D., Andrews, E., Biraud, S. C., and McFarquhar, G. M.: The DOE ARM Aerial Facility, B. Am. Meteorol. Soc., 95, 723-742, https://doi.org/10.1175/BAMS-D-13-00040.1, 2014.

Schmid, B., Ellingson, R. G., and McFarquhar, G. M.: ARM aircraft measurements, Meteor. Mon., 57, 10.1-10.13, https://doi.org/10.1175/AMSMONOGRAPHS-D-15-0042.1, 2016.

Schwarz, J. P., Gao, R. S., Spackman, J. R., Watts, L. A., Thomson, D. S., Fahey, D. W., Ryerson, T. B., Peischl, J., Holloway, J. S., Trainer, M., Frost, G. J., Baynard, T., Lack, D. A., de Gouw, J. A., Warneke, C., and Del Negro, L. A.: Measurement of the mixing state, mass, and optical size of individual black carbon particles in urban and biomass burning emissions, Geophys. Res. Lett., 35, L13810, https://doi.org/10.1029/2008GL033968, 2008.

Schwarz, J. P., Spackman, J. R., Gao, R. S., Watts, L. A., Stier, P., Schulz, M., Davis, S. M., Wofsy, S. C., and Fahey, D. W. Global-scale black carbon profiles observed in the remote atmosphere and compared to models, Geophys. Res. Lett., 37, L18812, https://doi.org/10.1029/2010GL044372, 2010.

Shaw, G. E.: The Arctic haze phenomenon, B. Am. Meteorol. Soc., 76, 2403-2413, https://doi.org/10.1175/15200477(1995)076<2403:TAHP>2.0.CO;2, 1995.

Shupe, M. D. and Intrieri, J. M.: Cloud radiative forcing of the Arctic surface: the influence of cloud properties, surface albedo, and solar zenith angle, J. Climate, 17, 616-628, https://doi.org/10.1175/15200442(2004)017<0616:CRFOTA>2.0.CO;2, 2004.

Stein, A. F., Draxler, R. R., Rolph, G. D., Stunder, B. J. B., Cohen, M. D., and Ngan, F.: NOAA's HYSPLIT Atmospheric Transport and Dispersion Modeling System, B. Am. Meteorol. Soc., 96, 2059-2077, https://doi.org/10.1175/BAMS-D-1400110.1, 2015.

Stevens, B. and Feingold, G.: Untangling aerosol effects on clouds and precipitation in a buffered system, Nature, 461, 607-613, https://doi.org/10.1038/nature08281, 2009. 
Stohl, A., Klimont, Z., Eckhardt, S., Kupiainen, K., Shevchenko, V. P., Kopeikin, V. M., and Novigatsky, A. N.: Black carbon in the Arctic: the underestimated role of gas flaring and residential combustion emissions, Atmos. Chem. Phys., 13, 8833-8855, https://doi.org/10.5194/acp-13-8833-2013, 2013.

Tietze, K., Riedi, J., Stohl, A., and Garrett, T. J.: Space-based evaluation of interactions between aerosols and low-level Arctic clouds during the Spring and Summer of 2008, Atmos. Chem. Phys., 11, 3359-3373, https://doi.org/10.5194/acp-113359-2011, 2011.

Tunved, P., Ström, J., and Krejci, R.: Arctic aerosol life cycle: linking aerosol size distributions observed between 2000 and 2010 with air mass transport and precipitation at Zeppelin station, Ny-Ålesund, Svalbard, Atmos. Chem. Phys., 13, 3643-3660, https://doi.org/10.5194/acp-13-3643-2013, 2013.

Twomey, S.: The effects of fluctuations in liquid water content on the evolution of large drops by coalescence, J. Atmos. Sci., 33, 720-723, https://doi.org/10.1175/15200469(1976)033<0720:TEOFIL>2.0.CO;2, 1976.

Warneck, P.: Chemistry of the Natural Atmosphere, vol. 71, Academic Press, San Diego, CA, USA, 1999.

Warneke, C., Bahreini, R., Brioude, J., Brock, C. A., de Gouw, J. A., Fahey, D. W., Froyd, K. D., Holloway, J. S., Middlebrook, A., Miller, L., Montzka, S., Murphy, D. M., Peischl, J., Ryerson, T. B., Schwarz, J. P., Spackman, J. R., and Veres, P.: Biomass burning in Siberia and Kazakhstan as an important source for haze over the Alaskan Arctic in April 2008, Geophys. Res. Lett., 36, L02813, https://doi.org/10.1029/2008GL036194, 2009.

Warneke, C., Froyd, K. D., Brioude, J., Bahreini, R., Brock, C. A., Cozic, J., de Gouw, J. A., Fahey, D. W., Ferrare, R., Holloway, J. S., Middlebrook, A. M., Miller, L., Montzka, S., Schwarz, J. P., Sodemann, H., Spackman, J. R., and Stohl, A.: An important contribution to springtime Arctic aerosol from biomass burning in Russia, Geophys. Res. Lett., 37, L01801, https://doi.org/10.1029/2009GL041816, 2010.
Weingartner, E., Burtscher, H., and Baltensperger, U.: Hygroscopic properties of carbon and diesel soot particles, Atmos. Environ., 31, 2311-2327, https://doi.org/10.1016/S1352-2310(97)00023X, 1997.

Welch, B. L.: The generalization of "student's" problem when several different population varlances are involved, Biometrika, 34, 28-35, https://doi.org/10.1093/biomet/34.1-2.28, 1947.

Wu, W. and McFarquhar, G. M.: On the impacts of different definitions of maximum dimension for nonspherical particles recorded by 2D imaging probes, J. Atmos. Ocean. Tech., 33, 1057-1072, https://doi.org/10.1175/JTECH-D-15-0177.1, 2016.

Zamora, L. M., Kahn, R. A., Cubison, M. J., Diskin, G. S., Jimenez, J. L., Kondo, Y., McFarquhar, G. M., Nenes, A., Thornhill, K. L., Wisthaler, A., Zelenyuk, A., and Ziemba, L. D.: Aircraftmeasured indirect cloud effects from biomass burning smoke in the Arctic and subarctic, Atmos. Chem. Phys., 16, 715-738, https://doi.org/10.5194/acp-16-715-2016, 2016.

Zaveri, R. A., Berkowitz, C. M., Brechtel, F. J., Gilles, M. K., Hubbe, J. M., Jayne, J. T., Kleinman, L. I., Laskin, A., Madronich, S., Onasch, T. B., Pekour, M. S., Springston, S. R., Thornton, J. A., Tivanski, A. V., and Worsnop, D. R.: Nighttime chemical evolution of aerosol and trace gases in a power plant plume: Implications for secondary organic nitrate and organosulfate aerosol formation, $\mathrm{NO}_{3}$ radical chemistry, and $\mathrm{N}_{2} \mathrm{O}_{5}$ heterogeneous hydrolysis, J. Geophys. Res.-Atmos., 115, D12304, https://doi.org/10.1029/2009JD013250, 2010.

Zhang, R., Khalizov, A. F., Pagels, J., Zhang, D., Xue, H., and McMurry, P. H.: Variability in morphology, hygroscopicity, and optical properties of soot aerosols during atmospheric processing, P. Natl. Acad. Sci. USA, 105, 10291-10296, https://doi.org/10.1073/pnas.0804860105, 2008. 